\title{
SUBSTITUIÇÃO PARCIAL DO FARELO DE SOJA POR URÉIA OU AMIRÉIA EM DIETAS PARA CABRAS EM LACTAÇÃO
}

\author{
RAQUEL HELENA ROCHA FERNANDES
}

Médico Veterinário

Orientador: Prof. ${ }^{a} \mathrm{Dr} .{ }^{a}$ IVANETE SUSIN

Dissertação apresentada à Escola Superior de Agricultura "Luiz de Queiroz", Universidade de São Paulo, para obtenção do titulo de Mestre em Agronomia, Área de Concentração: Ciência Animal e Pastagens.

PIRACICABA

Estado de São Paulo - Brasil

Maio - 2002 


\section{Dados Internacionais de Catalogação na Publicação (CIP) DIVISÃO DE BIBLIOTECA E DOCUMENTAÇĀO - ESALQ/USP}

\section{Fernandes, Raquel Helena Rocha}

Substituição parcial do farelo de soja por uréia ou amiréia em dietas para cabras em lactação / Raquel Helena Rocha Fernandès. - Piracicaba, 2002.

61 p. p.

Dissertação (mestrado) - - Escola Superior de Agricultura Luiz de Queiroz, 2002. Bibliografia.

1, Cabras 2. Dieta animal 3. Farelos 4. Lactação animal 5. Urèia I. Titulo

CDD 636.39085

"Permitida a cópia total ou parcial leste documento, descle que citada a fonte - 0 autor" 
"O coração tem razões que a própria razão desconhece."

Blaise Pascal

(1623-1662)

\section{Dedico}

Aos meus pais,

Antonio Pedro e Maria Olinda, pela confiança e ao meu irmão Victor Cesar, pela amizade. 


\section{AGRADECIMENTOS}

À Profa. Ivanete Susin pela amizade e dedicação demonstrada na orientação deste trabalho assim como pelo excelente exemplo profissional.

A todos os Professores e Funcionários do Departamento de Produção Animal da Escola Superior de Agricultura "Luiz de Queiroz".

À CAPES pela bolsa de estudos concedida.

Aos funcionários do Setor de Ovino e Caprinocultura, Sr. Roberto, Adilson e Alexandre pela colaboração e pelo bom ambiente de trabalho, assim como a Profa. Ivanete pela qualidade da estrutura destinada à pesquisa em pequenos ruminantes.

Aos estagiários do Setor de Ovino e Caprinocultura Clayton (Cirilo) e Vivian pela agradável convivência e valiosa ajuda durante a parte experimental.

Às trinta e três cabras leiteiras que colaboraram neste experimento.

Ao funcionário Carlos César Alves e à Carla Maris Bittar Nussio pela paciência e atenção dispensada durante as análises laboratoriais.

Ao Prof. Irineu Paker e a Claudia Paro da Paz pela ajuda na análise estatistica.

Aos Funcionários da Biblioteca Central pela agradável convivência.

Aos colegas de curso pela convivência durante o transcorrer do curso.

À Márcia, "Seu" Paulo, Ademir, Décio e Rafael pela "diversão" e "stress" dos seminários das disciplinas compartilhadas e ao Hugo pelas várias "dicas".

À Carolina pela agradável convivência, amizade e colaboração neste trabalho.

À "casa 4" Bibiana, Geni, e Vanderlei pela amizade e feliz convivência.

À Adriana (Joaninha), Adriana (Rod's), Débora (Magali) entre os vários amigos da $59^{\mathrm{a}}$ turma de Veterinária - USP pela eterna amizade e presença nas alegrias e tristezas.

Aos Professores da Faculdade de Medicina Veterinária e Zootecnia - USP principalmente pela confiança e amizade assim como pelo incentivo à pesquisa.

Ao Victor pela coragem, apoio e por tudo que compartilharmos.

Especial, a Deus pela minha vida e por ter aprendido a transformar tristezas e decepções em alegria, coragem e crescimento. 


\section{SUMÁRIO}

Página

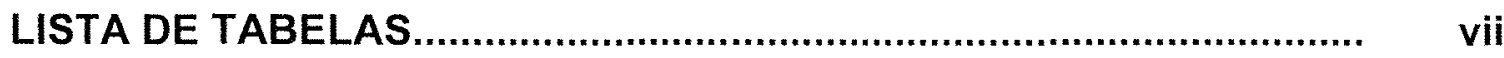

LISTA DE ABREVIATURAS............................................................ ix

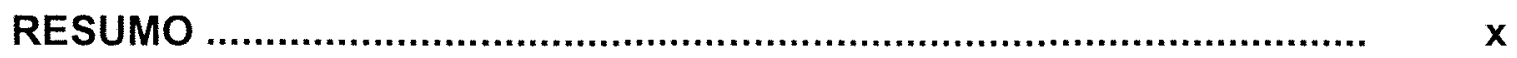

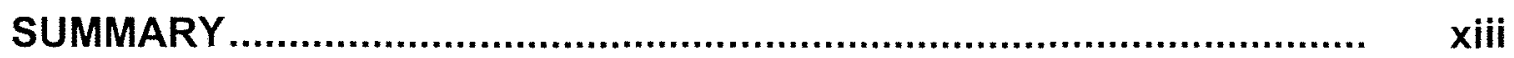

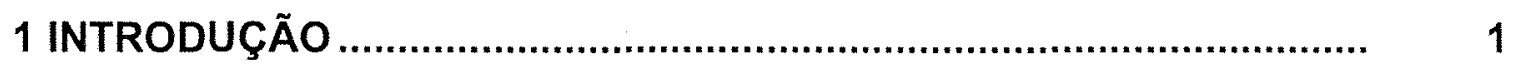

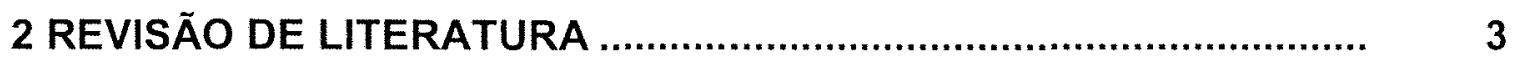

2.1 Caprinocultura leiteira atual ...............................................................

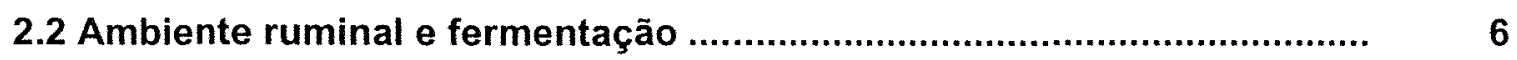

2.3 Uso de nitrogênio não proteico (NNP) na alimentação de ruminantes... 8

2.3.1 Uréia como fonte de nitrogênio ........................................................... 9

2.3.2 Uréia em complexos de liberação lenta .................................................. 12

2.3.3 Amiréia na alimentação de ruminantes..................................................... 13

2.3.4 Efeito do uso de NNP sobre o consumo de matéria seca (CMS) ......... 15

2.3.5 Efeito do uso de NNP sobre a produção de leite.................................... 17

2.3.6 Avaliação do perfil protéico dos animais ............................................... 19

3 MATERIAL E MÉTODOS ......................................................... 22 


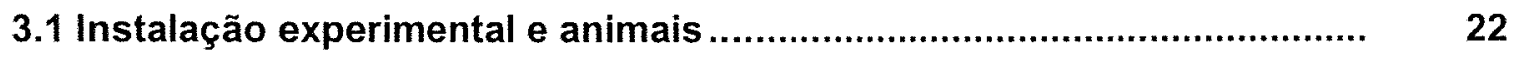

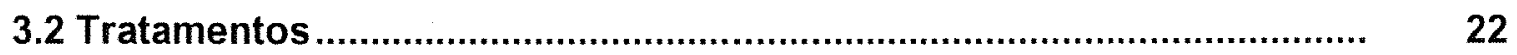

3.3 Período experimental .............................................................. $\quad 24$

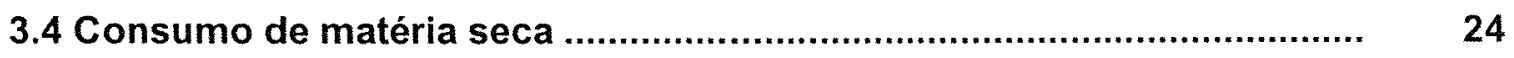

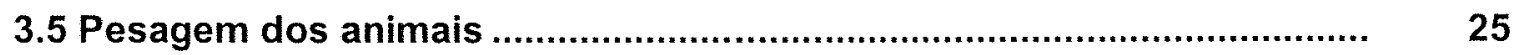

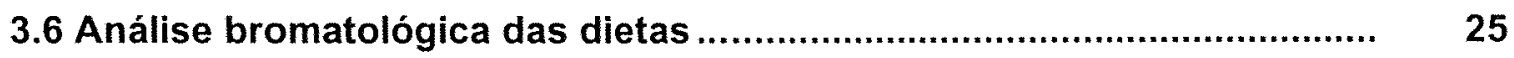

3.7 Determinação da produção e composição do leite ................................ 26

3.8 Determinação de glicose, $\mathrm{N}$ uréico e AGNE no plasma .......................... 27

3.9 Delineamento experimental e análise estatística .............................. 28

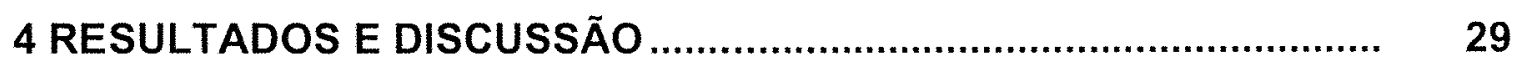

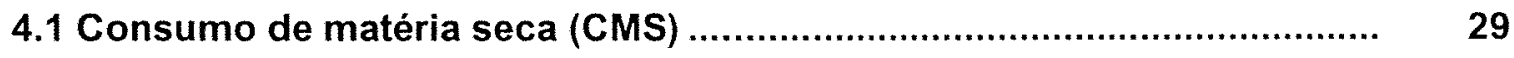

4.2 Alteração no peso vivo dos animais ............................................. 34

4.3 Produção e composição do leite ...................................................... $\quad 35$

4.4 Concentração plasmática de glicose ................................................ 42

4.5 Concentração de nitrogênio uréico plasmático (NUP) . .......................... 44

4.6 Concentração plasmática de ácidos graxos não esterificados (AGNE).. $\quad 46$

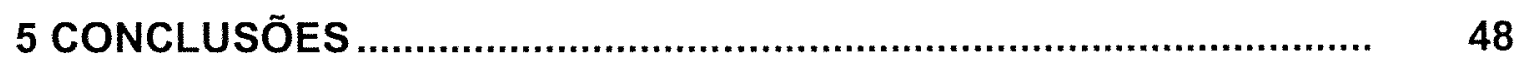

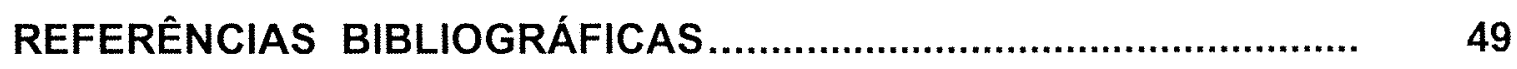




\section{LISTA DE TABELAS}

Página

1 Composição química das dietas (\% da MS) ........................... 23

2 Efeito da substituição parcial do farelo de soja por uréia ou amiréia sobre o consumo de matéria seca e nutrientes de cabras em lactação

3 Efeito da substituição parcial do farelo de soja por uréia ou amiréia sobre o CMS e nutriente de cabras em lactação.

4 Comparação entre o CMS obtido experimentalmente e os estimados pelo AFRC (1997) e pelo Sistema Francês Unités d'Encombrement Laitières (UEL).

5 Consumo médio de MS (kg/animal/dia) para as respectivas dietas experimentais durante as oito semanas experimentais.......

6 Efeito da substituição parcial do farelo de soja por uréia ou amiréia sobre o peso de cabras em lactação

7 Efeito da substituição parcial do farelo de soja por uréia ou amiréia sobre a eficiência na produção de leite de cabras em lactação.

8 Produção média semanal de leite ( $\mathrm{kg} / \mathrm{animal} / \mathrm{dia})$ para as oito semanas e para as dietas experimentais

9 Produção de leite corrigida para gordura em ( $\mathrm{kg} / \mathrm{dia}$ ) segundo Gravert (1987), para as oito semanas e para as dietas experimentais. 
10 Composição média do leite durante o periodo experimental.........

11 Efeito da substituição parcial do farelo de soja por uréia ou amiréia sobre a concentração plasmática de glicose de cabras em lactação.

12 Efeito da substituição parcial do farelo de soja por uréia ou amiréia sobre a concentração de $\mathrm{N}$ uréico (NUP) no plasma de cabras em lactação.

13 Efeito da substituição parcial do farelo de soja por uréia ou amiréia sobre a concentração de ácidos graxos não esterificados (AGNE) no plasma de cabras em lactação............................... 


\section{LISTA DE ABREVIATURAS}

CMS Consumo de matéria seca

CPB Consumo de proteína bruta

EE Extrato etéreo

$E L_{L} \quad$ Energia liquida de lactação

FDA Fibra em detergente ácido

FDN Fibra em detergente neutro

FS Tratamento farelo de soja

FS+AM Tratamento farelo de soja mais amiréia

FS+UR Tratamento farelo de soja mais uréia

MO Matéria orgânica

MODR Matéria orgânica degradável no rúmen

MS Matéria seca

$\mathrm{N} \quad$ Nitrogênio

NDT Nutrientes digestiveis totais

NNP Nitrogênio nãọ protéico

NUL Nitrogênio uréico no leite

NUP Nitrogênio uréico no plasma

PD Proteína digestivel

PB Proteína bruta 


\title{
SUBSTITUIÇÃO PARCIAL DO FARELO DE SOJA POR URÉIA OU AMIRÉIA EM DIETAS PARA CABRAS EM LACTAÇÃO
}

\author{
Autora: RAQUEL HELENA ROCHA FERNANDES \\ Orientadora: Prof. ${ }^{a}$ Dr. ${ }^{a}$ IVANETE SUSIN
}

\section{RESUMO}

Trinta e três cabras leiteiras (12 primiparas e 21 multíparas) foram utilizadas, num delineamento experimental de blocos inteiramente casualizados, para comparar o efeito da substituição parcial de farelo de soja por uréia ou amiréia sobre o desempenho na lactação e concentração de glicose, $N$ uréico e AGNE no plasma. Três dietas com $16 \%$ de PB, compostas de $40 \%$ de silagem de milho e $60 \%$ de concentrado na MS, foram utilizadas. As fontes nitrogenadas foram: farelo de soja (FS), farelo de soja mais $2,8 \%$ de amiréia (150\% de equivalente protéico) ( $F S+A M)$ e farelo de soja mais $1,5 \%$ de uréia ( $F S+U R)$. Não houve diferença $(P>0,05)$ entre os tratamentos para consumo de MS $(2,33 ; 2,18 ; 2,22 \mathrm{~kg} /$ animal/dia $)$, produção de leite $(2,76 ; 2,50 \mathrm{e}$ $2,49 \mathrm{~kg} / \mathrm{animal} / \mathrm{dia}), \%$ de gordura no leite $(3,92 ; 3,93$ e $4,09 \%)$ e $\%$ de proteína no leite $(3,03 ; 3,01$ e $2,99 \%)$ para os tratamentos FS, FS+AM e FS+UR, respectivamente. Não houve diferença para a concentração de glicose e AGNE no plasma $(P>0,05)$. Entretanto, a concentração de $N$ uréico plasmático (NUP) na colheita após quatro semanas, apresentou menor concentração para o tratamento FS. Após oito semanas, o tratamento FS+UR apresentou tendencia 
$(P=0,07)$ a maior NUP do que FS mas foi similar ao tratamento $F S+A M$. Este trabalho demonstrou a viabilidade do uso de uréia substituindo parcialmente o farelo de soja (1,5\% da MS) em dietas com $16 \%$ de PB para cabras leiteiras. Não houve benefício no desempenho da lactação com o uso da amiréia. 


\title{
PARCIAL REPLACEMENT OF SOYBEAN MEAL BY UREA OR STAREA IN DIETS FOR LACTATING GOATS
}

\author{
Author: RAQUEL HELENA ROCHA FERNANDES \\ Adviser: Prof. ${ }^{a}$ Dr. ${ }^{a}$ IVANETE SUSIN
}

\section{SUMMARY}

Thirty-three dairy goats (12 primiparous and 21 multiparous) were used in a completely randomized block design to compare the effects of partially replacing soybean meal by urea or starea on lactation performance, plasma glucose, plasma non-esterified fatty acids and plasma urea nitrogen. Three TMR (total mixed rations) containing $16 \% \mathrm{CP}$, with $40 \%$ corn silage and $60 \%$ concentrate were used. The nitrogen sources of the diets were soybean meal (FS), soybean meal plus starea (150\% protein equivalent) (FS+AM) and soybean meal plus urea ( $F S+U R)$. There were no differences $(P>0.05)$ among dietary treatments for dry matter intake $(2.33,2.18$ and $2.22 \mathrm{~kg} / \mathrm{d}$ ), milk production $(2.76,2.50$ and $2.49 \mathrm{~kg} / \mathrm{d})$, milk fat $(3.92,3.93$ and $4.09 \%)$ and milk protein $(3.03,3.01$ and $2.99 \%)$ for $F S, F S+A M$ and FS+UR, respectively. Plasma glucose and non-esterified fatty acids (NEFA) were not affected by $N$ sources $(P>0,05)$. However, plasma urea nitrogen (PUN) concentration was lower for FS treatment at the $4^{\text {th }}$ week of trial. On the other hand, at $8^{\text {th }}$ week of trial, the FS+UR had higher PUN than FS and similar to FS+AM. This study indicated that using urea or starea for lactating dairy goats had no detrimental effect on lactation performance. No benefits were found in using starea. 


\section{INTRODUÇÃo}

O emprego de novas técnicas de alimentação associadas ao melhoramento genético, controle reprodutivo eficiente e a prevenção das principais patologias, juntamente com a intensificação dos sistemas de produção, tornaram possivel o aumento da produtividade em caprinos nos últimos 30 anos, mesmo nas áreas menos desenvolvidas (Morand-Fehr \& Boyazoglu, 1998).

A alimentação de caprinos leiteiros em sistema intensivo é responsável pela maior parte dos custos de produção, ou seja, entre 55 e 75\% (Hadjipanayiotou, 1986). O nitrogênio não protéico (NNP) geralmente é utilizado com a finalidade de diminuir o custo com a alimentação. Entre as fontes de NNP, a uréia é a mais comum e de custo mais acessivel (Ezequiel et al., 2001). A incorporação de quantidades máximas de NNP nas rações de vacas leiteiras, tem demonstrado redução nos custos, sem diminuir a produtividade ou comprometer a saúde de bovinos (Huber \& Kung, 1981; Santos et al., 1998b).

Os microrganismos ruminais possuem a capacidade de sintetizar todos os aminoácidos essenciais e não essenciais a partir de fontes apropriadas de carbono, enxofre, nitrogênio não protéico (NNP), aminoácidos e peptídeos. Segundo Owens \& Zinn (1993) os bovinos têm a capacidade de crescer, reproduzir e produzir leite em dietas que contenham apenas NNP como fonte de nitrogênio. 
A quantidade de NNP que poderá ser utilizada para síntese de proteína microbiana depende da energia da dieta. A inclusão de fontes nitrogenadas não protéicas em dietas deve ser realizada de forma correta, principalmente quanto a sua associação a fontes de carboidrato, visando maximizar a produção de proteína microbiana (Santos et al.,1998b).

Alguns trabalhos já demonstraram a viabilidade do uso de uréia na produção de leite em caprinos, entretanto, a utilização de amiréia em cabras leiteiras ainda não foi estudada. O uso de NNP de liberação lenta reduziria efeitos adversos, permitindo o fornecimento de maiores quantidades de uréia sem causar sobrecarga de amônia ou decréscimo no consumo.

O objetivo deste trabalho foi comparar a substituição parcial do farelo de soja por NNP (uréia ou amiréia) na alimentação de cabras leiteiras em lactação. Os parâmetros avaliados foram:

$\checkmark$ consumo de matéria seca;

$\checkmark$ produção e composição de leite;

$\checkmark$ variação no peso corporal;

$\checkmark N$ uréico plasmático;

$\checkmark$ glicose plasmática;

$\checkmark$ ácidos graxos não esterificados (AGNE) no plasma. 


\section{REVISÃO DE LITERATURA}

\subsection{Caprinocultura leiteira atual}

A caprinocultura apresenta-se como um sistema de produção diferenciado, pois os consumidores finais, a forma de venda e o sistema de produção encontram-se sob grande influência cultural e histórica (Boyazoglu \& Morand-Fehr, 2001). Entretanto, mesmo estando ligada culturalmente à várias regiões, a produção de leite, assim como de carne de caprinos e ovinos somente sobreviverá as novas imposições do mercado comercial quando mostrar-se competitiva.

O leite proveniente de pequenos ruminantes representa aproximadamente $3,5 \%$ do total produzido no mundo, sendo que a proporção da produção proveniente de paises desenvolvidos é substancialmente maior que a dos paises em desenvolvimento (FAO, 1999). O volume de leite de vaca produzido em países desenvolvidos encontra-se relativamente estável nos últimos anos. Neste mesmo período ocorreu aumento na produção de leite de cabra $(+21 \%)$. Entretanto, a produtividade no setor de bovinos apresentou um aumento expressivo $(+77 \%)$ contrastando com o setor caprino $(+38 \%)$.

Em alguns locais, os produtos provenientes de pequenos ruminantes, representam quase o total de fontes protéicas na alimentação humana (Boyazoglu \& Morand-Fehr, 2001). Haenlein (2001) apontou que em 
alguns países, mais da metade ou pelo menos um terço de todo leite consumido é proveniente de ovinos e caprinos, contribuindo significativamente como fonte de proteína e cálcio na dieta da população.

A caprinocultura, assim como a ovinocultura leiteira, têm importância significativa para a economia de vários paises. Tal fato é especialmente verdadeiro quando observa-se a área mediterrânea, que inclui países como a França, Itália, Espanha e Grécia, mostrando que a produção leiteira de ovinos e caprinos não está necessariamente ligada a países em desenvolvimento (Haenlein, 2001). Na Europa, a produção média de leite por cabra é a mais elevada, sendo que a União Européia participa com $15 \%$ da produção mundial de leite caprino com apenas $2 \%$ do total do rebanho caprino mundial. Recentemente, a caprinocultura leiteira vem crescendo consideravelmente na Índia, Bangladesh e Irã, que contribuem atualmente com um terço da produção mundial de leite de cabra.

O Brasil possui cerca de 12,6 milhões de caprinos $(1,76 \%$ do rebanho mundial) e contribui com apenas $1,3 \%$ da produção de leite (FAO, 1999). Entretanto, na última década, o Brasil tem mostrado um crescimento considerável na produção leiteira caprina. O leite é o principal produto da caprinocultura no Centro-sul brasileiro, porém, no Nordeste onde a grande maioria do rebanho é voltada para a produção de carne e pele, a produção de leite também mostra sinais de aumento (Ribeiro, 1997). O leite de cabra vem conquistando o mercado, quer seja na forma de leite pasteurizado, pasteurizado congelado ou de leite em pó e mais recentemente em embalagens "Tetra Pak", tipo longa vida UHT, esterilizado e aromatizado (Cordeiro, 2001).

As características da lactação na espécie caprina são muito semelhantes as da bovina (INRA, 1988). O pico de lactação ocorre de um a dois meses após o parto com posterior declínio gradual. O peso vivo do animal é reduzido até aproximadamente seis semanas após o parto, e aumenta lentamente até o terço final da gestação. O consumo de matéria seca aumenta mais lentamente que a produção de leite, atingindo o pico na oitava semana 
após o parto quando, então diminui lentamente até estabilizar-se no terceiro mês de gestação. Assim como vacas leiteiras, as cabras leiteiras de boa produção apresentam um período de balanço energético negativo durante as primeiras semanas de lactação (Sutton \& Alderman, 2000).

Assim como nas vacas leiteiras, a composição do leite de cabras varia extensamente devido a vários fatores como dieta, fase da lactação e raça (AFRC, 1997).

O leite de cabra de raças não especializadas é muito semelhante ao da espécie ovina, possuindo alto teor de sólidos totais entre $(13,5$ e 17,5\%), gordura $(4,5$ a $6,5 \%)$ e proteina bruta $(4,0$ a $5,5 \%)$. Entretanto, raças leiteiras como a Saanen, a Parda Alpina e a Toggenburg, produzem leite com menor teor de sólidos totais $(11,0$ a $13,5 \%)$, o que está relacionado com menores teores de gordura $(3,0$ a $4,0 \%)$ e proteina $(2,7$ a $3,5 \%)$. Assim, pode-se observar que o leite de cabras especializadas é muito semelhante ao de bovinos no que se refere a conteúdo de sólidos totais (Morand-Fehr et al., 1991) apesar da concentração de lactose ser ligeiramente menor como evidenciado por Parkash \& Jenness (1968). Segundo Haenlein (2001), o leite de cabra é bastante semelhante ao bovino, embora não contenha beta-caroteno e aglutinina, apresentando menor quantidade de alfa-s-1-caseína e ácido fólico.

A concentração das diferentes frações nitrogenadas no leite de cabra é muito similar entre as raças, sendo que o $\mathrm{N}$ proveniente da caseina varia entre 73 e $76 \%$ do $N$ total. As estimativas para NNP no leite variam, com valores entre 10 e $17 \%$ refletindo concentrações lácteas de NNP entre 0,55 e $0,83 \mathrm{~g} / \mathrm{kg}$ de leite. Jenness (1980) demonstrou que a fração NNP estava próxima de $10 \%$ da fração nitrogenada ou seja entre 0,30 e $0,50 \mathrm{~g} / \mathrm{kg}$ de leite. Desde 1993, o AFRC adotou a fração nitrogenada proveniente de NNP como $10 \%$ do $\mathrm{N}$ total para o cálculo da proteína verdadeira no leite de cabra.

Os glóbulos de gordura do leite de cabra por serem de menor tamanho fazem com que este seja mais homogêneo e tenha uma melhor dispersão. Jenness (1980) relatou que o leite de cabra por não conter aglutinina 
na membrana de seus glóbulos de gordura, aglutina com menor facilidade que o leite de vaca. Entretanto, por formar coalho mais leve, a produtividade para produção de queijo é menor que aquela a partir do leite de vaca. Por outro lado, o menor tamanho de seus glóbulos de gordura e diferentes tipos de caseína facilitam a digestão (Haenlein, 2001).

\subsection{Ambiente ruminal e fermentação}

O ecossistema ruminal consiste de microrganismos de diferentes espécies ea fermentação ruminal vai depender da atividade que estes exercem no rúmen (Hungate, 1966). A relação entre os vários microrganismos ruminais deixa mais complexo o entendimento do ambiente ruminal (Russel \& Hespell, 1981). As bactérias encontradas no conteúdo ruminal podem ser provenientes da dieta ou do ambiente, entretanto, o rúmen permite apenas o crescimento de organismos para os quais o substrato e o pH ruminal são ideais, selecionando organismos que possuem uma alta taxa de divisão celular (Orskov, 1992).

Bryant (1963) e Hungate (1966) ao investigarem as exigências nutricionais de algumas bactérias ruminais indicaram que a amônia é essencial para o crescimento de bactérias como Bacteroides succinogenes, Ruminococcus flavefaciens, Ruminococcus albus, Bacteroides amylophilus, Methanobacterium ruminatium e Eubacterium ruminatium mesmo quando da presença de proteina verdadeira.

O nitrogênio não protéico (NNP) da dieta, nitrogênio salivar e possivelmente uma pequena porção de uréia que entra no rúmen via parede ruminal é convertido quase que totalmente a amônia. Assim, várias fontes de 
nitrogênio contribuem para a produção de amônia ruminal (Satter \& Roffler, 1975).

A relação positiva entre a conversão de fontes de nitrogênio para amônia e a magnitude da digestão de celulose e amido indicam a importância da amônia como um componente essencial para a digestão bacteriana da fibra e do amido (Helmer et al.,1970a). Hungate (1966), ao discutir sobre fermentação ruminal e crescimento microbiano, indicou que a extensão de síntese microbiana dependia também da quantidade de energia disponivel no substrato, principalmente carboidratos, e não somente da quantidade $e$ natureza do material presente no rúmen.

A quantidade de amônia que poderá ser utilizada pelas bactérias depende da quantidade de energia disponivel, ou seja, quantidade de alimento fermentescivel consumido. Alimentos com alto teor de nutrientes digestiveis totais (NDT) são geralmente mais fermentáveis. Portanto, mais amônia pode ser utilizada quando do fornecimento de alimentos com alto teor de NDT (Satter \& Roffler, 1975).

O amido parece ser a melhor fonte de energia para conversão de amônia em proteína pelos microrganismos ruminais (Helmer et al., 1970a). Sabe-se que a taxa de liberação da energia de amido cozido, é a mais próxima à taxa de liberação de amônia de compostos como a uréia, que possui uma rápida hidrólise em ambiente ruminal. A combinação destas fontes de energia e proteína pode aumentar a eficiência de utilização da amônia liberada, resultando em maior produção de proteina microbiana.

O National Research Council (1989) sugere que, a exigência de amônia está relacionada à disponibilidade do substrato, à taxa de fermentação, à massa microbiana e a produção do animal. Em dietas com baixo teor de proteina, o conteúdo ingerido de nitrogênio é o principal fator limitante da taxa de fermentação ruminal, assim como, da taxa de passagem dos alimentos pelo trato digestivo. O efeito do aumento da ingestão pelo aumento do teor de 
nitrogênio na dieta é atribuído a fermentação e taxa de passagem superiores (Chalupa, 1968; Russel, 1992; Owens e Zinn, 1993).

Quando grande quantidade de carboidratos são fermentados no rúmen, ultrapassando a velocidade de degradação da proteina, o crescimento microbiano e a eficiência digestiva são reduzidas. Isto é caracterizado pela fermentação incompleta, onde os microrganismos, deficientes em $\mathrm{N}$, desviam ATP para acúmulo de carboidrato e não para a síntese de proteína microbiana (Nocek \& Russel, 1988; Clark et al.,1992). A utilização sincronizada de proteina e carboidratos da dieta é necessária para um ótimo crescimento microbiano e síntese protéica (Russel \& Hespell, 1981), beneficiando a digestibilidade ruminal (Herrera-Saldana \& Huber, 1989 e Clark et al., 1992), a eficiência na utilização de proteína e energia, assim como a produção de leite (Herrera-Saldana \& Huber, 1989; Hoover \& Stockes, 1991).

\subsection{Uso de nitrogênio não proteico (NNP) na alimentação de ruminantes}

O nitrogênio dietético é normalmente classificado em componentes protéicos e não protéicos. Os componentes não protéicos incluem aminoácidos livres, peptídeos, ácidos nucléicos, amônia livre, sais de amônio, uréia, biureto, nitrato, assim como outros componentes que contém nitrogênio (Huber \& Kung, 1981).

O NNP geralmente é utilizado com a finalidade de diminuir o custo com a alimentação. Entre as fontes de NNP, a uréia é a mais comum e de custo mais acessivel (Santos et al., 1998a; Ezequiel et al., 2001). 


\subsubsection{Uréia como fonte de nitrogênio}

A uréia disponivel ao animal pode ter origem endógena e exógena. A uréia exógena, ou seja, a fornecida ao ruminante como fonte de nitrogênio para os microrganismos ruminais é um composto quaternário constituído por nitrogênio, oxigênio, carbono e hidrogênio $\left(\mathrm{CH}_{4} \mathrm{~N}_{2} \mathrm{O}\right.$ ) (Schmidt-Nielsen, 1996; Nelson \& Cox, 2000). O equivalente protéico da uréia alimentar é de $281 \%$, sendo produzida sinteticamente a partir de gás carbônico $\left(\mathrm{CO}_{2}\right)$ e amônia $\left(\mathrm{NH}_{3}\right)$.

A uréia endógena é sintetizada no figado pelo ciclo da uréia. A amônia absorvida pelo epitélio ruminal chega ao fígado pela veia porta reagindo com o gás carbônico $\left(\mathrm{CO}_{2}\right)$ formando carbamil fosfato, através da carbamil fosfato quinase. $\mathrm{O}$ ácido $\mathrm{N}$-acetil glutâmico é um fator necessário para formação de $\mathrm{CO}_{2}$. A ornitina reage com o carbamil fosfato formando citrulina e fosfato inorgânico. Na presença de trifosfato de adenosina (ATP) ocorre a reação de ácido aspártico com citrulina produzindo arginilsuccinato, sendo que esta reação é catalisada pela arginosuccinato sintetase. O ácido arginil succínico, é clivado pela argilsuccinase liberando ácido fumárico e arginina, que pela ação da arginase é desdobrada em ornitina e uréia (Schmidt-Nielsen, 1996; Nelson \& Cox, 2000). A uréia formada endógenamente pode ser eliminada via urina, retornar ao rúmen pela saliva ou por difusão pelo epitélio ruminal (Visek, 1984).

A urease presente no líquido ruminal quando em contato com a uréia leva a sua hidrólise desdobrando-a em $\mathrm{CO}_{2}$ e amônia. Possivelmente, a hidrólise da uréia também ocorre durante sua passagem pelo epitélio ruminal em decorrência da ação da urease bacteriana que penetra no tecido, o que de certa forma acelera a difusão desta para o rúmen (Houpt, 1970). Owens \& Berger (1983), relataram que a concentração de amônia no rúmen mostra o balanço entre suas fontes: degradação de proteina alimentar e de NNP, hidrólise de uréia reciclada e degradação do protoplasma microbiano; e as vias 
pela qual esta deixa o rúmen: utilização pelos microrganismos, absorção através da parede ruminal e passagem para o omaso.

A amônia formada a partir de uréia pela urease bacteriana é um eletrólito fraco possuindo duas formas em solução: a ionizada $\left(\mathrm{NH}_{4}\right)$ e a não ionizada $\left(\mathrm{NH}_{3}\right)$, as quais encontram-se em equilibrio sendo que suas respectivas concentrações dependem do $\mathrm{pH}$ e da temperatura (Visek, 1984). Segundo este mesmo autor, pequenos aumentos em pH acima de 7 provocam grandes aumentos na proporção de amônia não ionizada, sendo esta propriedade de grande importância, pois, juntamente com dados experimentais, assim como baseando-se em principios físico-químicos, deduziu-se que as membranas celulares são altamente permeáveis à forma não ionizada levando a rápido equilibrio entre as formas ionizada e não ionizada. Visek (1984) explica que a formação de gradiente ocorre quando há diferença de $\mathrm{pH}$ entre as membranas, levando a maior concentração de amônia em compartimentos com menor $\mathrm{pH}$, assim a concentração de amônia no líquido intracelular $(\mathrm{pH} 7,0)$ é quase 2,5 vezes a concentração no liquido extracelular $(\mathrm{pH} 7,4)$.

A concentração de amônia na circulação periférica é mantida baixa devido à conversão desta em uréia no figado. Existe um gradiente permanente que permite a absorção de amônia em excesso em relação à capacidade de utilização pelos microrganismos ruminais (Boin, 1994). O fígado normalmente é muito eficiente em remover a amônia da circulação, de forma que a concentração no sangue periférico permanece abaixo de $4 \mu$ Moles (Visek, 1984). Adicionalmente, a amônia pode chegar à circulação periférica sem ter passado pelo fígado, saindo do rúmen diretamente para o sistema linfático (Owens \& Berger, 1983).

Quando o fígado excede sua capacidade de conversão, as concentrações de amônia no sangue elevam-se, ocasionando uma alcalose sistêmica. A elevação do $\mathrm{pH}$ sangüíneo está associado com altas taxas de concentração de amônia no sangue, sendo que a diminuição do ciclo do citrato com glicólise anaeróbica compensatória pode causar uma queda no $\mathrm{pH}$ do 
sangue e a morte por intoxicação. Altas concentrações de amônia no sangue da carótida comparando com o sangue da jugular indicam uma rápida absorção da amônia pelo cérebro, sendo que os transtornos no sistema nervoso central são importantes fatores de intoxicação (Emerick, 1993). Além disso, também ocorrem alterações no metabolismo dos tecidos (Clark \& Davis, 1980; Visek, 1984).

O sistema de reciclagem da uréia foi verificado em caprinos por Fujihara \& Tasaki (1975), que observaram absorção de praticamente toda a uréia utilizada com a infusão em teores crescentes de uréia no abomaso. A quantidade de $\mathrm{N}$ nas fezes não foi alterada uma vez que a digestibilidade da PB aumentou linearmente com a infusão de uréia. Entretanto, houve aumento na excreção de $\mathrm{N}$ urinário.

Brun-Bellut (1996), ao verificar o efeito do estágio fisiológico e da composição da dieta na reciclagem de uréia pelo rúmen de cabras leiteiras, observou que cabras em lactação reciclavam mais uréia do que cabras gestantes e estas mais do que cabras no período seco.

Um dos maiores problemas na utilização da uréia ocorre devido à rápida liberação de amônia em relação a sua utilização (Chalupa, 1968 e Owens \& Zinn, 1993). A hidrólise da uréia ocorre quatro vezes mais rápido que sua utilização, resultando em perdas eventuais de nitrogênio disponivel para síntese de proteina microbiana conforme demonstrado em ovelhas fistuladas por Bloomfield et al. (1960) e Makkar et al. (1988). O aumento do $\mathrm{pH}$ ruminal ocorre quando da alimentação com uréia devido a rápida hidrólise desta em dióxido de carbono e amônia. Infelizmente, a capacidade tampão do fluído ruminal para bases não é tão grande quanto sua capacidade tamponante para ácidos (Bloomfield et al., 1966). Em animais adaptados à uréia, a taxa de hidrólise da uréia pode ser reduzida por inibição $\left(\mathrm{NH}_{4}\right)$ ou ainda por mecanismos das próprias espécies de microorganismos (Owens \& Zinn, 1993). Stiles (1970) demonstrou que a prévia exposição a uréia levava os animais a menor sensibilidade, e que animais adaptados conseguiram alimentar-se com 
quantidades duas vezes maiores que animais não adaptados. Russell et al. (1992) afirmaram que a produção excessiva de amônia, assim como o aumento na sua absorção leva a uma maior excreção de nitrogênio e a um maior gasto de energia para sintese de uréia. A excreção de uréia tem alto custo metabólico para o animal (Visek, 1984).

\subsubsection{Uréia em complexos de liberação lenta}

Métodos que tornem mais lenta a solubilidade da uréia no rúmen poderão conduzir a otimização da sua utilização em dietas para ruminantes, permitindo assim o fornecimento de maiores quantidades de uréia sem causar sobrecarga de amônia ou decréscimo no consumo de alimentos. Muhrer et al. (1968) observaram que a combinação de uréia e amido, através do aquecimento sobre pressão, levava a menor liberação da amônia quando comparada a uréia sem este tratamento.

No início da década de setenta, pesquisadores da Universidade de Kansas utilizaram um produto resultante da extrusão do amido com a uréia ao qual denominaram "starea" (Helmer et al., 1970a e b; Helmer \& Bartley, 1971). O processamento do grão e da uréia era realizado em um equipamento de cozimento e extrusão utilizado para produção de alimentos para animais de estimação. No Brasil, o produto resultante deste processamento recebeu o nome de amiréia, sendo a fonte de amido utilizada a raspa de mandioca integral (Maia et al., 1987).

Associações de uréia e cálcio são utilizadas como fontes alternativas para alimentação de ruminantes em confinamentos, melhorando a eficiência de ganho. A mistura peletizada de alfafa, uréia (32\%), fosfato bicálcico, sulfato de sódio e propionato de sódio foi denominada "Dehy 100" 
(100\% de PB). Conrad \& Hibbs (1979), utilizando o "Dehy 100" (40\% do N total), observaram resultados semelhantes a soja quando fornecido a vacas de alta produção.

Owens \& Zinn (1993) afirmaram que o sistema de reciclagem de nitrogênio no rúmen compensa facilmente a rapidez da liberação de amônia, sempre que as concentrações não são tóxicas. Assim, complexos de liberação lenta ajudam a evitar a intoxicação por amônia, porém, parecem não melhorar a eficiência de utilização do NNP.

\subsubsection{Amiréia na alimentação de ruminantes}

Amiréia, quando testada in vitro, foi ligeiramente superior ao grão expandido com uréia sugerindo que a reação do amido com a uréia pode levar a um produto que afeta a taxa de liberação de amônia. Isso foi evidenciado por maiores concentrações de proteína microbiana e menores de amônia no fluído ruminal (Helmer et al., 1970a).

Alguns estudos demonstraram um desempenho mais favorável quando da utilização de amiréia como fonte de NNP de liberação lenta. A amiréia foi superior a uréia associada ao milho e muito próxima ao farelo de soja para vacas leiteiras. Redução no teor de gordura do leite foi observada em ambos os tratamentos, amiréia ou farelo de soja, provavelmente pelo aumento da ingestão de grãos, o mesmo não ocorrendo quando do uso de uréia pois os animais consumiam menor quantidade de grãos (Helmer et al. , 1970b).

Stiles et al. (1970), utilizando dois bezerros com cânulas ruminais, observaram um aumento na utilização do nitrogênio da uréia assim como maior aceitabilidade das rações contendo amiréia como fonte de nitrogênio. Os 
autores relataram ainda que a suplementação com amiréia reduzia a concentração de amônia ruminal e aumentava a produção de proteína microbiana quando comparada à uréia. Além disso, foi observado que a amiréia levava a uma pronta ingestão o que não ocorria com as outras três formas de oferta de associação da uréia: a grão moído, peletizado ou expandido; devido a baixa palatabilidade da uréia. Quando foram utilizadas rações com $5 \%$ de uréia com grão de sorgo, apenas o tratamento que continha amiréia não precisou ser fornecido pela cânula ruminal, pois os animais recusavam-se a ingerir os outros tratamentos.

Salman et al. (1997), em estudo sobre a digestibilidade in vivo para determinação do valor nutricional de rações para ovinos em crescimento, suplementadas com fontes de $N$ (farelo de algodão, amiréia ou uréia), observaram que entre os coeficientes de digestibilidade de matéria seca, o tratamento com amiréia obteve superioridade sobre os demais tratamentos. Não foram observadas diferenças entre o coeficiente de digestibilidade de proteina bruta, balanço de nitrogênio e quantidades de nitrogênio não protéico nas fezes. Também não foram observadas diferenças quanto ao consumo de matéria seca em relação à fonte de proteína utilizada. A adição de amiréia em rações com silagem de milho não aumentou a ingestão de matéria seca, mas aumentou a digestibilidade desta, quando comparada à uréia e ao farelo de algodão. A utilização da amiréia e, ou, uréia, como suplemento protéico exclusivo de rações para ovinos em crescimento contendo alto teor de volumosos, mostrou-se uma alternativa viável sob os aspectos estudados.

Teixeira et al. (1998), comparando fontes de NNP associadas ao sal mineral para bovinos em sistema de pastejo, observaram que o tratamento com amiréia resultou em ganho de peso superior em relação ao tratamento com uréia e ainda ao tratamento no qual a uréia foi misturada a raspa de mandioca e enxofre.

O estudo de desempenho de bovinos confinados e alimentados com dietas de silagem de milho ( $63 \%$ da MS) e concentrados ( $37 \%$ da MS) a base 
farelo de algodão, uréia ou amiréia (com $30 \%$ de proteína bruta), não foram encontradas diferenças em relação ao ganho de peso, ingestão de MS em \% $\mathrm{PV}$, em $\mathrm{g} / \mathrm{kg}^{0,75} / \mathrm{dia}$ ou $\mathrm{kg} / \mathrm{animal} / \mathrm{dia}$ durante o período experimental de 80 dias (Seixas et al., 1999).

\subsubsection{Efeito do uso de NNP sobre o consumo de matéria seca (CMS)}

Alterações no consumo de MS em animais recebendo uréia foram observadas em alguns estudos. Segundo Huber \& Kung (1981), a diminuição no consumo de alimentos com o uso de altas quantidades de uréia na dieta pode ocorrer em animais, mesmo quando estes foram adaptados fisiologicamente. De acordo com Huber (1978), a redução no consumo em vacas ao ingerirem quantidades moderadas de uréia ocorre devido a sua baixa aceitabilidade e não por motivos ruminais ou pós ruminais.

O proposto mecanismo de ação da uréia sobre o consumo, devido a aceitabilidade, não é sustentado por alguns autores. Wilson et al. (1975) avaliaram o consumo de bovinos em dietas com $1 \%$ e $3 \%$ de uréia, com diferentes formas de administração: 1 ou $3 \%$ de uréia $(15,85 \%$ PB) fornecida pela dieta; $1 \%$ de uréia na dieta e $2 \%$ via cânula ruminal e $1 \%$ de uréia na dieta com $2 \%$ de uréia via infusão ruminal contínua. Todas as dietas com mais de $1 \%$ de uréia reduziram o consumo, independentemente da forma de administração, o que indica que a palatabilidade não foi o único fator nesta redução. Os autores sugeriram que metabólitos intermediários da uréia podem ser os responsáveis pela diminuição da ingestão de alimentos, quando o teor de uréia na ração total está acima de $1 \%$.

Boin (1994) postulou que o uso de uréia como fonte de nitrogênio para ruminantes pode, quando em quantidade que provoque intoxicações subagudas, ser responsável pela depressão no consumo de alimentos. 
Campbell et al. (1963) demonstraram a importância do aumento da freqüência de alimentação, quando do uso de uréia para alimentação de novilhas leiteiras em crescimento. Os autores utilizaram uma ração com 3,3\% de uréia oferecida em seis vezes diárias e observaram que o crescimento e a eficiência alimentar foram superiores quando comparados a dois fornecimentos diários e similares aos obtidos em animais alimentados com dieta de suplemento protéico de origem vegetal. Entretanto, tal prática dificulta o manejo alimentar do rebanho.

Helmer et al. (1970b) observaram que bovinos recebendo farelo de soja ou amiréia ( $23 \%$ da PB), como suplemento protéico via concentrado, consumiam maior quantidade de MS quando comparados a animais recebendo premix com uréia ( $14,5 \%$ de uréia e $85,5 \%$ de grão de milho).

Trabalhando com vacas leiteiras canuladas, Carmo (2001) não verificou diferença no CMS e na digestibilidade aparente dos nutrientes no trato digestivo total, quando da substituição parcial do farelo de soja por $2 \%$ de uréia ou o equivalente em amiréia.

A utilização de NNP na alimentação de caprinos não é tão freqüente quanto em bovinos. Considerando a aceitabilidade como um fator importante na redução de consumo, os caprinos talvez sejam mais sensiveis ao sabor amargo da uréia, e que limitaria seu uso a teores menores do que os utilizados por bovinos. Alguns estudos mostraram a viabilidade do uso de uréia para cabras em lactação. Entretanto, os dados revelaram contradição quanto ao teor máximo de substituição sem limitar a ingestão de matéria seca. Segundo Rindsig (1977), a utilização de uréia para caprinos leiteiros não deve ultrapassar $1 \%$ da MS total da dieta, ou a substituição de NP por NNP deve ser inferior a $30 \%$ do total de proteína da dieta, para que não ocorra redução no consumo. Santos \& Bose (1985) não observaram diferença no CMS total (volumoso e concentrado) por quilograma de peso metabólico com a inclusão de 0,$4 ; 0,8$ ou $1,2 \%$ da MS de uréia, em dietas para em cabras em lactação. Entretanto, os autores observaram que a medida que se aumentou o teor de uréia na dieta 
houve redução no consumo de concentrado por quilo de peso metabólico com tendência de aumento do consumo de volumoso.

Comparando a uréia e o biureto ( $50 \%$ da PD da dieta) com torta de amendoim, Singhal \& Mudgal (1982), não detectaram diferenças quanto ao CMS e a digestibilidade de dietas com palha de trigo fornecidas para caprinos machos adultos.

Fernandez et al. (1988), ao alimentarem cabras primíparas com dietas contendo: $9,5 \%$ de $\mathrm{PB}, 14 \%$ de $\mathrm{PB}$ e $14 \%$ de $\mathrm{PB}$ com $33 \%$ do $\mathrm{N}$ fornecido na forma de uréia $(0,75 \%$ de uréia na MS) não observaram diferenças no CMS em relação a utilização de uréia. Do mesmo modo, Fernandez et al. (1997), ao avaliarem os efeitos da utilização de uréia (0,75 ou 1,28\% da MS) na dieta de cabras leiteiras sobre o desempenho da lactação, não verificaram diferença no CMS.

Singhal \& Mudgal (1984) também não relataram diferenças de CMS quando cabras em lactação receberam até $50 \%$ do $\mathrm{N}$ dietético na forma de uréia. Por outro lado, em um trabalho anterior, estes autores observaram aumento do CMS (89 $\mathrm{gMS} / \mathrm{kgPV}^{0,75}$ e $96 \mathrm{gMS}^{\mathrm{kgPV}}{ }^{0,75}$ ) quando o teor de substituição pela uréia foi de $50 \%$ do $N$ total (Singhal \& Mudgal,1982).

\subsubsection{Efeito do uso de NNP sobre a produção de leite}

Santos \& Bose (1985) observaram redução na produção de leite de cabras (33kg de PV e $6,5 \mathrm{~kg}$ de leite/semana) quando a uréia $(0,4 ; 0,8 ; 1,2 \%$ da MS) substituiu parcialmente farelo de soja e de algodão. A fonte de volumoso utilizada foi cana-de-açúcar constituindo $70 \%$ da MS. Por outro lado, Khan et al. citado por Brun-Bellut et al. (1991) relataram que a produção leiteira de cabras alimentadas com $36 \%$ de caroço de algodão (controle) ou concentrado 
contendo $1 \%$ de uréia associado a $24 \%$ de caroço de algodão não apresentavam diferenças quanto a produção de leite e leite corrigido para gordura. Entretanto, animais que receberam 2 ou $3 \%$ de uréia em suas dietas apresentaram menor produção de leite corrigido que os animais controle ou com $1 \%$ de uréia.

Fernandez et al. (1997), ao substituírem 25,33 ou $50 \%$ do $\mathrm{N}$ da dieta por $\mathrm{N}$ da uréia, não encontraram diferença em relação a produção de leite assim como teor de gordura no leite. Entretanto, os autores postulam que a fração nitrogenada do leite poderá ser afetada comprometendo suas propriedades de processamento quando do uso de altos teores de NNP $(50 \%$ da PB).

Os efeitos do uso de NNP sobre a produção de vacas leiteiras tem sido amplamente estudado. Broderick et al. (1993), ao compararem suplementação com proteína verdadeira ou com uréia em dietas com silagem de alfafa e milho na alimentação de vacas leiteiras, não observaram diferenças em produção de leite assim como nos teores de proteina e gordura do leite.

Em uma vasta revisão de literatura sobre o uso de NNP em bovinos leiteiros, Santos et al. (1998b) relataram que a substituição, parcial ou total, da proteína verdadeira por uréia, em um total de 23 comparações, não afetou a produção de leite em 20 estudos, e aumentou o teor de proteína em 5, com vacas produzindo em média $34,5 \mathrm{~kg} / \mathrm{dia}$.

Recentemente, Imaizumi (2000) verificou que a uréia (1,3\% da MS) associada ao farelo de soja, foi tão eficiente quanto o farelo de soja em suprir aminoácidos à glândula mamária de vacas em final de lactação produzindo entre 12 e $13 \mathrm{~kg}$ de leite/dia.

Poucos estudos foram realizados com utilização de amiréia em substituição a uréia para vacas leiteiras tendo sido obtidos resultados variados. Helmer et al. (1970b) ao analisarem a produção e a composição do leite, observaram que animais recebendo farelo de soja ou amiréia produziram mais leite do que os animais recebendo premix com uréia. Os autores relataram 
ainda que, a quantidade de sólidos totais no leite não foi afetada pelas fontes de nitrogênio (farelo de soja, amiréia ou uréia).

Jones et al. (1975), ao avaliarem a utilização de rações completas para vacas em lactação com uréia, amiréia ou farelo de soja, não observaram diferenças na produção e no teor de gordura do leite. Por outro lado, RomanPonce et al. (1975), mostraram que vacas alimentadas com uréia apresentaram menor produção de leite quando comparadas ao farelo de soja ou amiréia, entretanto, a produção de leite corrigida para gordura foi semelhante entre os tratamentos.

Recentemente, Carmo (2001), ao substituir parcialmente farelo de soja por uréia ( $2 \%$ ) ou amiréia na dieta de vacas leiteiras em final de lactação (20 kg de leite/dia) não observou diferença na produção de leite e leite corrigido para $3,5 \%$ de gordura, assim como na concentração de proteina e lactose do leite. Entretanto, teor de gordura do leite foi afetado pelos tratamentos sendo maior para o tratamento com uréia.

\subsubsection{Avaliação do perfil protéico dos animais}

O aumento de ingestão de $\mathrm{N}$ influencia os metabólitos nitrogenados ruminais, sangüineos e o $\mathrm{N}$ uréico do leite (NUL). A concentração de $\mathrm{N}$ uréico no plasma pode ser afetada por vários fatores como teor e degradabilidade ruminal da proteina da dieta, potencial de produção e estágio de lactação (Blowey, 1992).

Vários fatores podem influir no aumento de NUP: aumento da ingestão de proteina; aumento da proporção de PDR, já que resultaria em uma maior proporção de proteína dietética sendo convertida em amônia; diminuição na ingestão de energia disponível para sintese de proteina microbiana, 
aumentando a saída de amônia pela parede ruminal; aumento do $\mathrm{pH}$ ruminal levando a aumento de $\mathrm{NH}_{3}$, o qual atravessa a parede ruminal com maior velocidade que $\mathrm{NH}_{4}$; aumento do catabolismo e ou falência renal $(\mathrm{NRC}, 1989)$.

Broderick \& Clayton (1997), ao estudarem a relação entre as concentrações de $\mathrm{N}$ uréico no leite e no plasma assim como, a capacidade da utilização da concentração de $N$ uréico no leite (NUL) em demonstrar o perfil protéico dos animais, relataram como fatores de relevância: teor de PB da dieta, relação PB:ELL (Mcal), consumo excessivo de $N$ e concentração de amônia ruminal.

A proporção de proteina degradável e não degradável no rúmen tem uma relação próxima com a quantidade de uréia circulando no sangue $e$, consequentemente, na concentração de uréia no leite. A amônia ruminal, uréia do sangue ou plasma e uréia no leite estão altamente correlacionadas (BrunBellut et al., 1983; DePeters \& Ferguson, 1992; Burchard \& Block, 1998). Em caprinos, Lu et al. (1990) e Sahlu et al. (1993b) verificaram que o aumento da ingestão de PB elevou a concentração de amônia ruminal, porém, não apresentou diferença na concentração de nitrogênio uréico no plasma.

Dietas com quantidade inadequada de energia podem ocasionar excesso de amônia ruminal, desencadeando aumento da concentração de $\mathrm{N}$ uréico plasmático associado a redução na concentração de proteína no leite (NRC, 1989).

Brun-Bellut et al. (1983) demonstraram, em caprinos, que o NUL foi altamente correlacionado com a utilização do $\mathrm{N}$ digestivel para mantença assim como à produção de leite. A concentração de NUL foi ainda correlacionada com a quantidade de $N$ na urina $(r=0,64 ; n=281)$ ou com a quantidade de uréia na urina $(r=0,72)$. Os autores concluíram que a concentração de $N$ uréico no leite estava correlacionada com a diferença entre o $\mathrm{N}$ digerido e a produção de $\mathrm{N}$ do leite assim como ao teor de proteína degradável no rúmen (PDR). Assim, foi sugerido que concentrações de NUL acima de $30,0 \mathrm{mg} / \mathrm{dL}$ poderiam indicar um excesso de PDR, proteina digerida ou ainda dieta pobre em energia. Por 
outro lado, quando o NUL for menor que $30,0 \mathrm{mg} / \mathrm{dL}$ pode estar indicando baixa quantidade de PDR ou proteina digerida. O NUL pode ser substituído por PUN ou ainda pela concentração de $N$ uréico no plasma (NUP), já que a correlação entre NUL e NUP é alta $(r=0,92 ; n=144)$ (Brun-Bellut et al., 1987). 


\section{MATERIAL E MÉTODOS}

\subsection{Instalação experimental e animais}

O experimento foi conduzido nas instalações do Sistema Intensivo de Produção de Ovinos e Caprinos do Departamento de Produção Animal, da Escola Superior de Agricultura "Luiz de Queiroz", Campus Piracicaba, Universidade de São Paulo. O município de Piracicaba situa-se no estado de São Paulo, a $22^{\circ} 42^{\prime} 30^{\prime \prime} S$ de latitude e $47^{\circ} 38^{\prime} 01^{\prime \prime} \mathrm{W}$ de longitude, com altitude média de $546 \mathrm{~m}$.

Foram utilizadas trinta e três cabras das raças Saanen e Parda Alpina com $110 \pm 6$ dias em lactação, sendo 12 primiparas e 21 multiparas. As cabras foram alojadas em baias individuais do tipo "tie-stall" $(0,5 \times 1,2 \mathrm{~m}) \mathrm{em}$ galpão coberto, com piso ripado, providas de comedouro individual e bebedouro.

\subsection{Tratamentos}

Os animais foram alimentados uma vez ao dia com ração total, sempre após a ordenha da tarde, permitindo uma sobra de $15 \%$ do total oferecido. A silagem e o concentrado eram pesados separadamente e homogeneizados manualmente no cocho. As dietas continham $16 \%$ de PB e 
eram compostas por $40 \%$ de silagem de milho e $60 \%$ de concentrado (Tabela 1).

Tabela 1. Composição das dietas experimentais (\% da MS).

\begin{tabular}{|c|c|c|c|}
\hline & \multicolumn{3}{|c|}{ Dietas $^{1}$} \\
\hline & FS & $\mathrm{FS}+\mathrm{AM}$ & FS+UR \\
\hline \multicolumn{4}{|l|}{ Ingredientes } \\
\hline Silagem de milho & 40,1 & 40,1 & 40,1 \\
\hline Milho moido & 29,9 & 37,2 & 38,5 \\
\hline Farelo de soja $48 \%$ & 17,3 & 7,2 & 7,2 \\
\hline Minerais e vitaminas ${ }^{2}$ & 2,4 & 2,4 & 2,4 \\
\hline Caroço de algodão & 10,3 & 10,3 & 10,3 \\
\hline Amiréia & -- & 2,8 & - \\
\hline Uréia & -- & -- & 1,5 \\
\hline \multicolumn{4}{|l|}{ Composição bromatológica } \\
\hline Matéria seca (MS) & 53,2 & 53,1 & 53,1 \\
\hline Proteína bruta (PB) & 16,43 & 16,70 & 16,87 \\
\hline Fibra detergente neutro (FDN) & 36,21 & 37,16 & 36,75 \\
\hline Fibra detergente ácido (FDA) & 20,53 & 20,80 & 20,53 \\
\hline Extrato etéreo (EE) & 4,67 & 4,83 & 4,78 \\
\hline Energia Liq. Lact., Mcal/kg MS ${ }^{3}$ & 1,76 & 1,76 & 1,76 \\
\hline \multicolumn{4}{|c|}{ 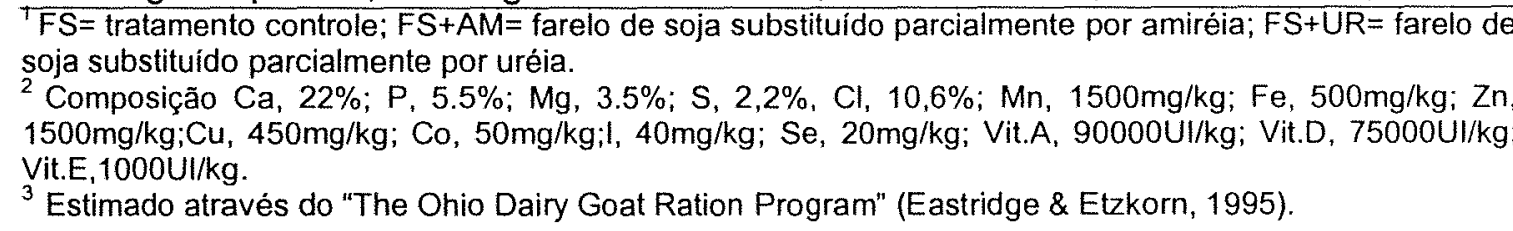 } \\
\hline
\end{tabular}

No tratamento controle (FS) a principal fonte de $\mathrm{N}$ era o farelo de soja, o qual foi substituido parcialmente por uréia $(1,5 \%$ da MS) ou amiréia ( $2,8 \%$ de MS) constituindo os tratamentos FS+UR e FS+AM, respectivamente. 
As dietas foram balanceadas para atender ou exceder as exigências de cabras em lactação (NRC, 1981 e Brun-Bellut et al., 1991).

\subsection{Periodo experimental}

Os animais foram submetidos a um periodo pré-experimental com 2 semanas de duração para adaptação as instalações e obtenção de dados para ajuste do periodo experimental; o qual teve duração de 8 semanas. A produção de leite, o peso dos animais e o CMS registrados durante a segunda semana do período pré-experimental e utilizados para a formação dos blocos e serviram como covariável na análise final dos dados experimentais.

\subsection{Consumo de matéria seca}

O CMS por animal/dia foi obtido através da diferença entre a quantidade de MS fornecida e as sobras. Foram colhidas amostras semanais do alimento fornecido para posterior análise. As amostras foram conservadas a $-10^{\circ} \mathrm{C}$ e posteriormente descongeladas, fracionadas e secas em estufa com ventilação forçada a $55^{\circ} \mathrm{C}$ por 72 horas para determinação da matéria seca (MS) de acordo com AOAC (1990).

Os dados de CMS obtidos foram comparados aos estimados pela equação publicada pelo AFRC (1997) a qual foi estabelecida por Morand-Fehr (1981) para cabras em lactação (10 a 30 semanas), sendo posteriormente modificada por Alderman (1982):

$\checkmark \operatorname{CMS}(\mathrm{kg} / \mathrm{d})=0,42 \times P L C G+0,024 P V^{0,75}+0,4 \triangle P V+0,7 F p$ 
Onde: PLCG: produção de leite corrigido para 3,5\% de gordura; PV: peso vivo dos animais, em $\mathrm{kg}$; $\triangle \mathrm{PV}$ : mudança no $\mathrm{PV}$ em $\mathrm{kg} /$ mês $\mathrm{Fp}$ : proporção decimal de forragem na dieta.

Além da comparação anterior, os dados também foram comparados com os resultados da aplicação da equação para estimativa de consumo utilizada pelo sistema francês UEL (Unités d'Encombrement Laitières) do AFRC (1997) estabelecida por Morand-Fehr \& Sauvant (1988):

$\checkmark \operatorname{CMS}(\mathrm{kg} / \mathrm{d})=0,062 \mathrm{PV}^{0,75}+0,305$ PLCG

Onde: PV: peso vivo dos animais, em $\mathrm{kg}$;

PLCG: produção de leite corrigido para $3,5 \%$ de gordura.

\subsection{Pesagem dos animais}

Os animais foram pesados no início e no final do período experimental, logo após a ordenha da manhã, por três dias consecutivos.

\subsection{Análise bromatológica das dietas}

As análises bromatológicas foram realizadas no Laboratório de Bromatologia do Departamento de Produção Animal, da Escola Superior de Agricultura "Luiz de Queiroz", Universidade de São Paulo. 
Após a determinação da matéria seca (MS) as amostras foram moídas em moinho tipo "Wiley" providos de peneiras de $1 \mathrm{~mm}$. As amostras moídas foram utilizadas para determinação de matéria orgânica $(\mathrm{MO})$, extrato etéreo ( $E E$ ) e proteína bruta (PB) de acordo com AOAC. (1990). As determinações de fibra em detergente neutro (FDN) de acordo com Van Soest et al (1991) e de fibra em detergente ácido (FDA) de acordo com Goering \& Van Soest (1970). A MS total foi obtida de acordo com o protocolo do laboratório de Bromatologia do Departamento de Produção Animal da ESALQ.

\subsection{Determinação da produção e composição do leite}

Os animais foram ordenhados duas vezes ao dia (7:30 e 15:30 h.) sendo a produção de leite determinada por pesagem semanal. Amostras compostas de leite (ordenha da manhã e da tarde) foram colhidas, semanalmente, no dia da pesagem. As amostras foram conservadas em 2bromo-2nitropropano-1-3-diol sob refrigeração $\left(6^{\circ} \mathrm{C}\right)$ para posterior determinação de proteina, gordura, lactose e sólidos totais. As determinações foram realizadas por leitura de absorção de infravermelho próximo em um equipamento Bentley 2000 (Bentley, 1995) no Laboratório de Análise de Leite do Departamento de Produção Animal da ESALQ - USP.

A produção de leite corrigida para $3,5 \%$ de gordura foi estabelecida, pela fórmula abaixo relacionada, segundo Gravert (1987).

$$
\checkmark \operatorname{LCG}(3,5 \%)=0,4337 \mathrm{PL}+16,218 \mathrm{PG}
$$

Onde: LCG: leite corrigido para gordura;

PL: produção de leite $(\mathrm{kg} / \mathrm{dia})$;

PG: produção de gordura ( $\mathrm{kg} / \mathrm{dia})$. 
O valor energético para leite caprino foi calculado pela fórmula sugerida pelo AFRC (1997). Esta foi desenvolvida baseando-se na equação proposta para leite bovino por Tyrell \& Reid (1965), a qual prediz o valor energético em decorrência de sua concentração de sólidos totais, sendo o componente de principal importância o teor de gordura.

$$
\begin{aligned}
& \checkmark V E_{1}=0,0376 P G+0,0209 P P+0,948 \\
& \text { Onde: } V E_{1} \text { : valor energético do leite } \\
& P P: \text { produção proteína }(\mathrm{g} / \mathrm{kg} \text { leite }=\% \text { litro } \times 9,71) ; \\
& P G: \text { produção de gordura }(\mathrm{g} / \mathrm{kg} \text { leite }) .
\end{aligned}
$$

\subsection{Determinação de glicose, $N$ uréico e AGNE no plasma}

No primeiro dia experimental assim como na quarta e na oitava semana do periodo experimental foram realizadas colheitas de sangue, antes e três horas após a alimentação (Gustafsson \& Palmquist, 1993) para determinação da concentração plasmática de glicose, $N$ uréico e ácidos graxos não esterificados. As colheitas foram realizadas em tubos a vácuo com $5 \mathrm{mg}$ de fluoreto de sódio e $5 \mathrm{mg}$ oxalato de potássio (Vacuum II; Labnew Indústria e Comércio Ltda., São Paulo, Brasil). Imediatamente após a colheita era realizada a separação do plasma sangüíneo por centrifugação (2000g). As amostras de plasma foram congeladas em dois tubos do tipo "ependorf" logo após a centrifugação para posterior determinação do $N$ uréico, glicose plasmática e AGNE.

Para determinação de nitrogênio uréico no plasma foi utilizado o método colorimétrico descrito por Chaney \& Marbach (1962), adaptado para 
leitura em placas de microtitulo em aparelho do tipo Elisa Reader (BIO RAD) com comprimento de luz de 540 nanômetros. Somente foram aceitos resultados provenientes de placas com $r^{2}=0,99$ e coeficiente de variação de $5 \%$ entre duplicatas.

A concentração plasmática de AGNE foi determinada através da utilização de kit comercial (Wako Chemicals $\mathrm{GmbH}$, Neuss, Alemanha), adaptado para leitura em placas de microtítulo, em aparelho do tipo Elisa Reader (BIO RAD) com comprimento de luz 540 nanômetros. Somente foram aceitos resultados provenientes de placas com $r^{2}>0,97$ e coeficiente de variação de $5 \%$ entre duplicatas.

A glicose plasmática foi estabelecida no autoanalisador bioquimico YSI 2700-S Biochem (Yellow Springs Instrument Co. Inc., Ohio, EUA).

\subsection{Delineamento experimental e análise estatística}

O delineamento utilizado foi o de blocos casualizados, sendo os blocos arranjados de acordo com a ordem de lactação (primeira ou demais), dias em lactação, produção de leite e peso dos animais. Os dados préexperimentais foram utilizados para ajustar por covariável os parâmetros estudados como: CMS, produção e composição do leite e parâmetros sangüineos. Os dados foram analisados pelo PROC MIXED do pacote estatístico SAS (1999). 


\section{RESULTADOS E DISCUSSÃO}

\subsection{Consumo de matéria seca (CMS)}

O CMS e de nutrientes para os três tratamentos durante o período experimental encontra-se na Tabela 2.

Tabela 2. Efeito da substituição parcial do farelo de soja por uréia ou amiréia sobre o consumo de matéria seca e de nutrientes de cabras em lactação.

\begin{tabular}{lccccc}
\hline Variável $^{2}$ & FS & $\begin{array}{c}\text { Dietas }^{1} \\
\text { FS+AM }\end{array}$ & FS+UR & EPM $^{3}$ & $P$ \\
\hline CMS, kg/d & 2,33 & 2,18 & 2,22 & 0,08 & 0,64 \\
CPB, g/d & 382,8 & 363,4 & 374,7 & 12,87 & 0,56 \\
CEE, g/d & 108,8 & 105,5 & 106,3 & 3,73 & 0,73 \\
CFDN, g/d & 843,6 & 809,9 & 816,1 & 28,96 & 0,71 \\
CFDA, g/d & 478,3 & 453,7 & 450,2 & 17,05 & 0,69
\end{tabular}

$\overline{F S}=$ tratamento controle; $F S+A M=$ farelo de soja substituido parcialmente por amiréia; $F S+U R=$ farelo de soja substituido parcialmente por uréia.

2 variável: $\mathrm{CMS}=$ consumo de matéria seca; $\mathrm{CPB}=$ consumo de proteina bruta; $\mathrm{CEE}=$ consumo de extrato etéreo; CFDN = consumo de fibra em detergente neutro; $C F D A=$ consumo de fibra em detergente ácido.

${ }^{3} E P M=$ erro padrão da média.

Não houve diferença no CMS $(P=0,64), C P B(P=0,56), C E E$ $(P=0,73)$, CFDN $(P=0,71)$ e CFDA $(P=0,69)$ durante todo o período 
experimental (Tabela 2) assim como nos dois períodos experimentais (Tabela 3) e ainda para a interação tratamento $x$ semana.

Tabela 3. Efeito da substituição parcial do farelo de soja por uréia ou amiréia sobre o consumo de MS de cabras em lactação durante os períodos experimentais.

\begin{tabular}{|c|c|c|c|c|c|}
\hline \multicolumn{6}{|c|}{ Dietas $^{\top}$} \\
\hline Variável & FS & $F S+A M$ & $F S+U R$ & $\mathrm{EPM}^{2}$ & $P$ \\
\hline \multicolumn{6}{|l|}{ Periodo 1} \\
\hline CMS, kg/d & 2,45 & 2,33 & 2,35 & 0,06 & 0,60 \\
\hline$\% \mathrm{PV}$ & 3,70 & 3,55 & 3,51 & 0,09 & 0,58 \\
\hline $\mathrm{g} / \mathrm{kgP} V^{0,75}$ & 105,56 & 100,57 & 101,47 & 2,50 & 0,37 \\
\hline CPB, g/d & 402,8 & 387,8 & 395,5 & 9,60 & 0,49 \\
\hline \multicolumn{6}{|l|}{ Periodo 2} \\
\hline CMS, kg/d & 2,22 & 2,02 & 2,07 & 0,10 & 0,67 \\
\hline$\% P V$ & 3,70 & 3,34 & 3,46 & 0,17 & 0,53 \\
\hline $\mathrm{g} / \mathrm{kgPV}^{0,75}$ & 94,48 & 86,84 & 89,48 & 4,67 & 0,54 \\
\hline CPB, g/d & 365,2 & 337,2 & 350,7 & 16,0 & 0,64 \\
\hline \multicolumn{6}{|l|}{ Periodo total } \\
\hline CMS, kg/d & 2,33 & 2,18 & 2,22 & 0,08 & 0,64 \\
\hline$\% P V$ & 3,50 & 3,33 & 3,31 & 0,12 & 0,55 \\
\hline $\mathrm{g} / \mathrm{kgPV}^{0,75}$ & 90,01 & 85,17 & 77,69 & 6,83 & 0,44 \\
\hline $\mathrm{CPB}, \mathrm{g} / \mathrm{d}$ & 382,8 & 363,4 & 374,7 & 12,87 & 0,56 \\
\hline \multicolumn{6}{|c|}{$\begin{array}{l}\text { FS = tratamento controle; FS+AM = farelo de soja substituido parcialmente por amiréia; FS+UR = farelc } \\
\text { de soja substituido parcialmente por uréia. } \\
\text { 'EPM = erro padrăo da média. }\end{array}$} \\
\hline \multicolumn{6}{|c|}{$\begin{array}{l}\text { O consumo médio de MS (\% PV) das cabras (Tabela } 3 \text { ) está de } \\
\text { rdo com Randy et al. (1986) onde cabras alpinas recebendo } 15,5 \text { e } 18,1 \% \\
\text { PB apresentaram consumos médios de } 3,4 \text { e } 3,7 \% \text { PV, respectivamente. }\end{array}$} \\
\hline
\end{tabular}


Segundo o AFRC (1997), o consumo médio de MS para cabras leiteiras em lactação é de $119,6 \mathrm{~g} / \mathrm{kgPV}^{0,75}$. No presente experimento, o CMS foi de $90,01,85,17$ e $77,69 \mathrm{~g} / \mathrm{kgPV}^{0,75}$ para os tratamentos $F S$, FS+AM e $\mathrm{FS}+\mathrm{UR}$, respectivamente. O CMS $\left(\mathrm{g} / \mathrm{kgPV}^{0,75}\right)$ encontrado neste experimento foi semelhante ao obtido por Singhal \& Mudgal (1980) em cabras leiteiras para dieta sem uréia e com uréia ( 89 e $96 \mathrm{~g} / \mathrm{kgPV}^{0,75}$, respectivamente).

Tabela 4. Comparação entre o CMS obtido experimentalmente e os estimados pelo AFRC (1997) e pelo Sistema Francês Unités d'Encombrement Laitières (UEL).

Dietas

\begin{tabular}{lccc} 
Variável & FS & FS+AM & FS+UR \\
\hline CMS, kg/d & 2,33 & 2,18 & 2,22 \\
CMSE $(\text { AFRC) })^{2}, \mathrm{~kg} / \mathrm{d}$ & 1,77 & 1,76 & 1,74 \\
$\quad$ CMS/CMSE(AFRC) $)^{2}$ & 1,32 & 1,24 & 1,28 \\
CMSE $(\text { UEL })^{3}, \mathrm{~kg} / \mathrm{d}$ & 2,35 & 2,26 & 2,29 \\
\multicolumn{1}{c}{ CMS/CMSE $(\mathrm{UEL})^{3}$} & 0,99 & 0,96 & 0,97
\end{tabular}

$\mathrm{FS}=$ tratamento controle; $F S+A M=$ farelo de soja substituido parcialmente por amiréia; $F S+U R=$ farelo de soja substituído parcialmente por uréia.

${ }^{2} \mathrm{CMSE}=\mathrm{CMS}$ estimado pela fórmula: $\mathrm{CMS}(\mathrm{kg} / \mathrm{d}) 0,42 \times \mathrm{PLCG}+0,024 \mathrm{PV}^{0,75}+0,4 \triangle \mathrm{PV}+0,7 \mathrm{Fp}$.

${ }^{3} \mathrm{CMSE}=\mathrm{CMS}$ estimado pela fórmula: CMS $(\mathrm{kg} / \mathrm{d})=0,062 \mathrm{PV}^{0,75}+0,305 \mathrm{PLCG}$.

O CMS observado neste experimento foi $31,63,23,86$ e $27,58 \%$ maior do que o estimado pela equação de Morand-Fehr (1981) (Tabela 4) para os tratamentos FS, FS+AM e FS+UR, respectivamente. O AFRC (1997) publicou que o mesmo ocorreu em vários outros experimentos, onde o CMS obtido foi aproximadamente $14 \%$ maior que o calculado por esta equação.

O Sistema Francês "Unités d'Encombrement Laitières" (UEL) foi o melhor em predizer o CMS pelo animais deste experimento. O CMS para as 
dietas experimentais foi em média $2,64 \%$ menor que o estimado. A fórmula utilizada pelo sistema Francês foi desenvolvida para animais alimentados com silagem de milho ou feno de alfafa como volumoso. Os animais neste experimento foram alimentados com silagem de milho.

Não foram encontradas diferenças no CMS ao longo das oito semanas de periodo experimental (Tabela 5).

Tabela 5. Consumo médio de MS (kg/animal/dia) para as respectivas dietas durante as oito semanas experimentais.

\begin{tabular}{ccccc}
\hline Semana & FS & $\begin{array}{c}\text { Dietas } \\
\text { FS+AM }\end{array}$ & FS+UR & Média semanal \\
\hline 1 & 2,41 & 2,37 & 2,31 & 2,36 \\
2 & 2,45 & 2,33 & 2,41 & 2,40 \\
3 & 2,35 & 2,27 & 2,28 & 2,30 \\
4 & 2,50 & 2,33 & 2,35 & 2,39 \\
5 & 2,34 & 2,18 & 2,21 & 2,24 \\
6 & 2,39 & 2,13 & 2,18 & 2,23 \\
7 & 2,11 & 1,91 & 2,01 & 2,01 \\
8 & 2,11 & 1,93 & 2,01 & 2,02 \\
Média dieta & 2,33 & 2,18 & 2,22 &
\end{tabular}

${ }^{\top} \mathrm{FS}=$ tratamento controle; $\mathrm{FS}+\mathrm{AM}=$ farelo de soja substituido parcialmente por amiréla; $F S+U R=$ farelo de soja substituido parcialmente por uréia.

Fernandez et al. (1997) não evidenciaram diferença quanto ao CMS, em cabras leiteiras, quando da utilização de uréia $(25,33$ e $50 \%$ do total de $\mathrm{N}$ da dieta), assim como Singhal \& Mudgal (1984) onde até $50 \%$ do $\mathrm{N}$ da dieta foi fornecido na forma de uréia. Carvalho (1989), substituindo $15 \%$ da proteina bruta da dieta de cabras por uréia, não observou diferença no CMS.

Por outro lado, Ahmed et al. (2001) relataram que o tratamento de palhada de sorgo com uréia levou a redução no CMS $(P<0,01)$. MacGregor \& 
Hodge (1988), também observaram redução no CMS uréia com o uso de 1,4\% de uréia na MS. Santos \& Bose (1985) verificaram redução no CMS de dietas para caprinos com uréia, quando o teor de adição foi superior a $0,4 \%$ da MS.

Para Rindsig (1977.), a suplementação com uréia não deve ultrapassar $1 \%$ da MS total da dieta. Este autor relata que sempre que a substituição de proteina verdadeira por NNP for superior a $30 \%$ do total de N da dieta, esta poderá levar à redução no CMS. Neste experimento o teor de uréia foi de $1,5 \%$ da MS ou $25 \%$ do nitrogênio total e não houve redução no CMS.

Em bovinos leiteiros vários estudos observaram o CMS em relação a utilização de uréia na dieta. Trabalhos com vacas em lactação, onde a uréia substituiu o farelo de soja, em dietas cujo volumoso foi silagem de milho mostraram que não houve efeito sobre o CMS (Plumer et al.,1971; Broderick, 1986; Broderick et al., 1993). Do mesmo modo, outros autores utilizando diferentes fontes de volumosos, não constataram efeito da inclusão de uréia no CMS (Baterman et al., 1994; Baker et al., 1995 e Lines \& Weiss, 1996; Guidi, 1999; Imaizumi, 2000). Entretanto, Santos et al. (2001) observaram menor CMS com a inclusão de $1 \%$ de uréia na MS em dietas com silagem de milho.

Oliveira et al. (2001) verificaram menor CMS com a inclusão de 1,4 e $2,1 \%$ da MS de uréia em dietas para vacas leiteiras, entretanto o CMS foi semelhante entre os tratamentos $0,7 \%$ de uréia e farelo de soja. Por outro lado, Santos et al. (1998a), observaram que a uréia foi capaz de aumentar o CMS em dietas com feno de alfafa em relação ao farelo de soja e farinha de peixe, para vacas em lactação.

Carmo (2001) observou resultado semelhante a este experimento, não encontrando diferenças no CMS quando da substituição de farelo de soja por uréia (2\%) ou amiréia em dietas para vacas em lactação. Roman-Ponce et al. (1975) e Helmer et al., (1970b) relataram menor CMS para o tratamento com uréia, e semelhante entre os tratamentos amiréia e farelo de soja $(P<0,01)$. 


\subsection{Alteração no peso vivo dos animais}

$\mathrm{O}$ peso final das cabras não foi afetado pela fonte de $\mathrm{N}$ utilizada neste experimento $(P=0,11)$. A variação de peso vivo durante o periodo experimental também não foi afetada pela fonte de $N$ nas dietas $(P=0,45)$.

Fernandez et al. (1997) relataram que o ganho de peso em cabras leiteiras em lactação não foi alterado $(P<0,10)$ pela utilização de NNP. Helmer et al. (1970b), avaliando premix com farelo de soja, amiréia ou uréia para vacas, observaram perda de peso nas vacas que receberam premix com uréia. Os autores concluíram que a produção, além de menor, foi parcialmente proveniente de reserva corporal. Entretanto, Carmo (2001), assim como neste experimento, não encontrou variação do peso corporal de vacas em lactação.

Tabela 6. Efeito da substituição parcial do farelo de soja por uréia ou amiréia sobre o peso de cabras em lactação.

\begin{tabular}{lccccc}
\hline & \multicolumn{5}{c}{ Dietas $^{1}$} \\
Variável & FS & FS+AM & FS+UR & EPM $^{2}$ & P \\
\hline Peso inicial, kg & 67,11 & 63,04 & 68,54 & 1,92 & 0,14 \\
Peso final, kg & 67,76 & 62,82 & 68,65 & 2,00 & 0,11 \\
Variação no PV, kg & 0,67 & $-0,21$ & 0,11 & 0,50 & 0,45
\end{tabular}

$\overline{F S}=$ tratamento controle; $F S+A M=$ farelo de soja substituido parcialmente por amiréia; $F S+U R=$ farelo de soja substituido parcialmente por uréia.

${ }^{2}$ EPM = erro padrão da média. 


\subsection{Produção e composição do leite}

Foi observada tendência de maior produção de leite e leite corrigido para 3,5\% de gordura, das cabras em lactação, pelo tratamento farelo de soja, quando comparado ao tratamento com substituição parcial do farelo de soja por uréia ou amiréia (Tabela 7).

A utilização da fórmula sugerida pelo AFRC (1997) para calcular o valor energético do leite de cabra mostra que os tratamentos apresentaram valores semelhantes $(P=0,63)$. Também não houve diferença quando do cálculo para eficiência na produção de leite $(P=0,46)$.

Tabela 7. Efeito da substituição parcial do farelo de soja por uréia ou amiréia sobre a eficiência na produção de leite de cabras em lactação.

\begin{tabular}{lccccc}
\hline Variável $^{2}$ & FS & FS+AM & FS+UR & EPM $^{3}$ & $\mathrm{P}$ \\
\hline Leite, $\mathrm{kg} / \mathrm{d}$ & 2,76 & 2,50 & 2,49 & 0,08 & 0,08 \\
LCG 3,5\%, kg/d & 2,97 & 2,75 & 2,75 & 0,09 & 0,10 \\
EA (LCG/CMS) & 1,28 & 1,26 & 1,24 & 0,01 & 0,46 \\
VE, Mj/kg & 1,16 & 1,16 & 1,16 & 0,006 & 0,63
\end{tabular}

${ }^{T} \mathrm{FS}=$ tratamento controle; $F S+\overline{A M}=$ farelo de soja substituido parcialmente por amiréia; $F S+U R=$ farelo de soja substituido parcialmente por uréia.

${ }^{2}$ Variável: $\angle C G=$ produção de leite corrigida para 3,5\% de gordura (Gravert, 1987); $E A=$ eficiência na produção de leite; $V E=$ valor energético para leite caprino (Morand-Fehr \& Sauvant, 1978).

${ }^{3} E P M=$ erro padrão da média.

Nas Tabelas 8 e 9 encontram-se as produções semanais de leite (kg/animal/dia) e produção de leite corrigida para $3,5 \%$ de gordura, respectivamente. 
Tabela 8. Produção média semanal de leite $(\mathrm{kg} / \mathrm{animal} / \mathrm{dia})$ para as oito semanas e para as dietas experimentais.

\begin{tabular}{lcccc}
\hline Semana & FS & $\begin{array}{c}\text { Dietas } \\
\text { FS+AM }\end{array}$ & FS+UR & Média semanal \\
\hline 1 & 3,06 & 2,80 & 2,93 & 2,93 \\
2 & 2,74 & 2,66 & 2,52 & 2,64 \\
3 & 2,80 & 2,47 & 2,52 & 2,60 \\
4 & 2,77 & 2,38 & 2,43 & 2,53 \\
5 & 2,60 & 2,48 & 2,46 & 2,51 \\
6 & 2,56 & 2,23 & 2,22 & 2,34 \\
7 & 2,66 & 2,46 & 2,33 & 2,49 \\
8 & 2,85 & 2,49 & 2,54 & 2,63 \\
Média dieta & 2,76 & 2,50 & 2,49 &
\end{tabular}

${ }^{T} \mathrm{FS}=$ tratamento controle; $F S+A M=$ farelo de soja substituido parcialmente por amiréia; $F S+U R=$ farelo de soja substituido parcialmente por uréia.

Tabela 9. Produção de leite corrigida para gordura em (kg/dia) segundo Gravert (1987), para as oito semanas e para as dietas experimentais.

\begin{tabular}{lcccc}
\hline Semana & FS & $\begin{array}{c}\text { Dietas }^{1} \\
\text { FS+AM }\end{array}$ & FS+UR & Média semanal \\
\hline 1 & 3,16 & 2,98 & 3,09 & 3,08 \\
2 & 2,92 & 2,87 & 2,77 & 2,85 \\
3 & 3,08 & 2,76 & 2,84 & 2,89 \\
4 & 2,98 & 2,48 & 2,58 & 2,69 \\
5 & 2,76 & 2,69 & 2,74 & 2,73 \\
6 & 2,84 & 2,52 & 2,53 & 2,63 \\
7 & 2,89 & 2,89 & 2,59 & 2,79 \\
8 & 3,00 & 2,78 & 2,80 & 2,86 \\
Média dieta & 2,96 & 2,75 & 2,74 & \\
\hline
\end{tabular}

FS= tratamento controle; $F S+A M=$ farelo de soja substituído parcialmente por amiréia; $F S+U R=$ farelo de soja substituido parcialmente por uréia. 


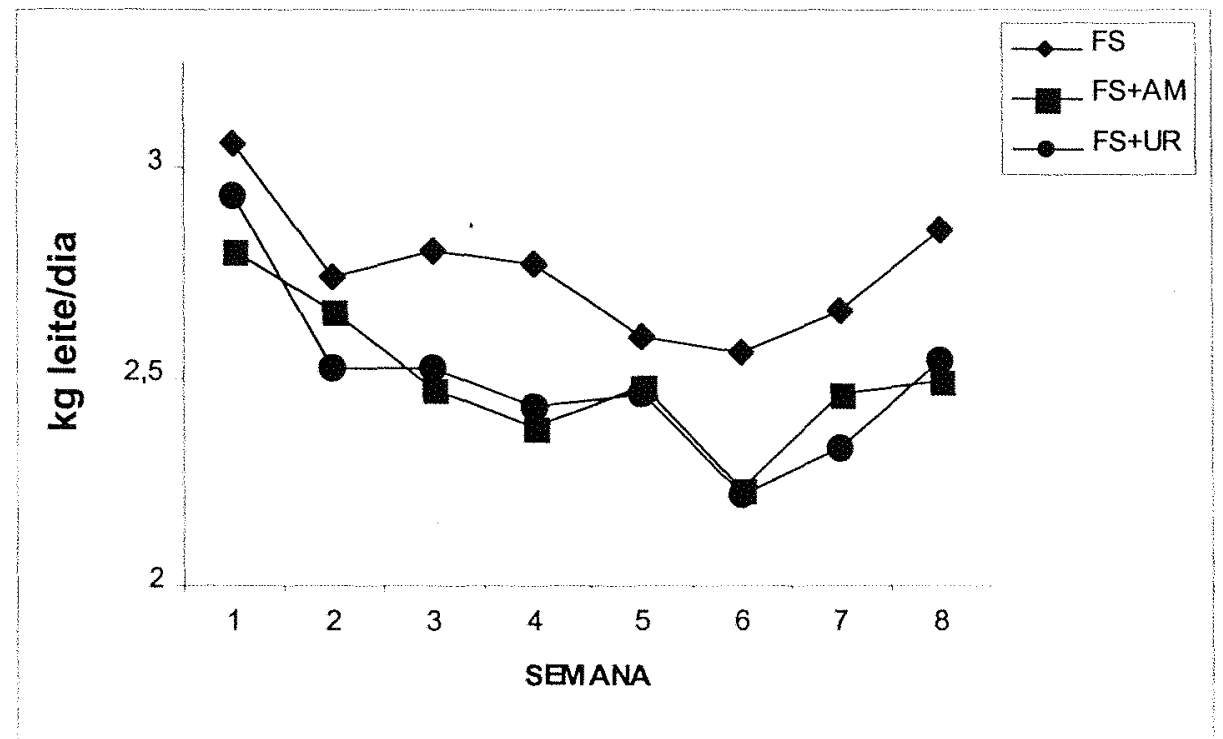

Figura 1 - Produção média semanal de leite (kg/animal/dia) para as oito semanas e para as dietas experimentais.

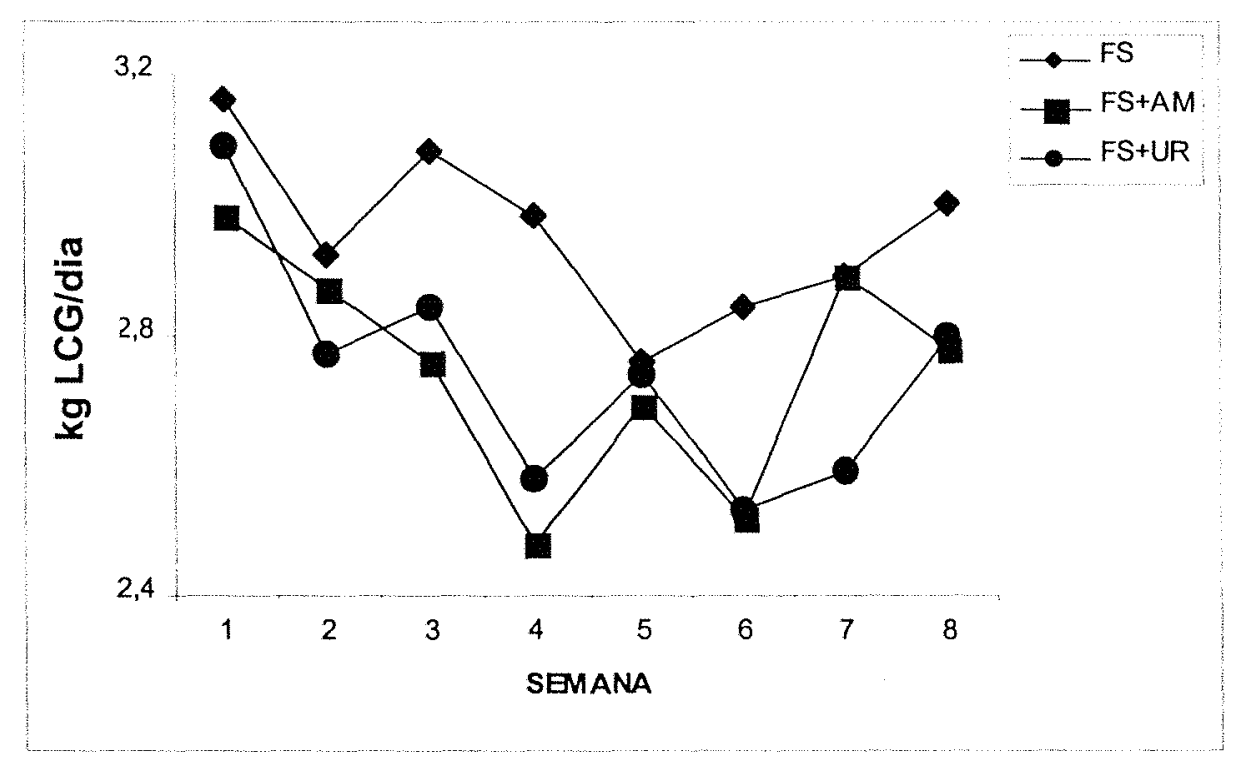

Figura 2 - Produção de leite corrigida para gordura em ( $\mathrm{kg} / \mathrm{dia}$ ) segundo Gravert (1987), para as oito semanas e para as dietas. experimentais. 
Os resultados de trabalhos sobre a substituição parcial de farelo de soja por uréia ou amiréia na produção de leite em bovinos é controverso. Assim como neste experimento com cabras, Jones et al. (1975) e Carmo (2001) com vacas leiteiras, não observaram diferenças na produção de leite. Já, RomanPonce et al. (1975) e Helmer et al. (1970b) verificaram menor produção de leite quando da substituição do farelo de soja por uréia, sem diferença para os tratamentos farelo de soja e amiréia. Roman-Ponce et al. (1975) observaram que a produção de leite corrigida para gordura foi semelhante pois o tratamento com uréia apresentou teor de gordura superior aos tratamentos com farelo de soja e amiréia. Em bovinos, a utilização de uréia não afetou a produção de leite em vários trabalhos (Plumer et al., 1971; Broderick et al., 1993; Guidi, 1999; Imaizumi, 2000).

$\mathrm{Na}$ alimentação de cabras leiteiras, MacGregor \& Hodge (1988) e Santos \& Bose (1985), ao estudarem o efeito da suplementação de uréia (1,4\% da MS e $04,0,8$ e $1,2 \%$ da $M S$, respectivamente), observaram que a suplementação com uréia resultou em menor produção de leite. A produção de leite corrigida para gordura em cabras consumindo $2 \%$ e $3 \%$ de uréia foi menor que aquela dos animais que recebiam a dieta controle ou a dieta com apenas 1\% de uréia (Hadjipanayiotou \& Morand-Fehr, 1991).

Ao utilizarem uréia associada com torta de caroço de algodão para alimentação de cabras leiteiras, Khan et al. citado por Brun-Bellut et al.(1991), não relataram diferenças em leite corrigido para gordura na dieta controle ( $36 \%$ de torta de caroço de algodão) comparada com dieta contendo $1 \%$ de uréia associada a $24 \%$ de torta de caroço de algodão. Alguns trabalhos em bovinos mostram que quando do uso de uréia ocorreu aumento na percentagem de gordura no leite (Carmo, 2001). Quando a substituição é em detrimento a uma fonte de gordura, que geralmente também leva a um aumento no teor de gordura no leite, os valores de gordura no leite se equiparam. 
Semelhante ao ocorrido neste experimento, Fernandez et al. (1997), ao utilizar uréia $(25,33$ e 50\% do $N$ total) na dieta de cabras leiteiras em lactação, não constaram diferenças para produção de leite e leite corrigido para gordura $4 \%(P>0,10)$.

A composição média de leite obtida neste experimento (Tabela 10) é condizente com o esperado por ser este um rebanho especializado, ou seja, muito semelhante a composição do leite bovino (Morand-Fehr et al., 1991).

Tabela 10. Composição média do leite durante o periodo experimental.

\begin{tabular}{lccccc}
\hline Variável & DS & $\begin{array}{c}\text { Dietas }^{1} \\
\text { FS+AM }\end{array}$ & FS+UR & EPM $^{2}$ & $P$ \\
\hline $\begin{array}{l}\text { Leite, kg/d } \\
\text { Gordura do leite }\end{array}$ & 2,76 & 2,50 & 2,49 & 0,09 & 0,08 \\
$\quad \%$ & 3,92 & 3,93 & 4,09 & 0,10 & 0,33 \\
g/d & 109,55 & 101,39 & 101,50 & 4,51 & 0,36 \\
$\begin{array}{l}\text { Proteina do leite } \\
\quad \%\end{array}$ & 3,03 & 3,01 & 2,99 & 0,04 & 0,62 \\
g/d & 84,00 & 76,54 & 78,09 & 2,97 & 0,20 \\
Lactose & & & & & \\
$\quad \%$ & 4,65 & 4,66 & 4,66 & 0,04 & 0,97 \\
g/d & 128,73 & 118,07 & 118,76 & 3,44 & 0,07
\end{tabular}

Sólidos totais

$\begin{array}{lccccc}\% & 12,44 & 12,40 & 12,52 & 0,16 & 0,88 \\ \mathrm{~g} / \mathrm{d} & 344,21 & 313,44 & 318,88 & 10,06 & 0,10\end{array}$

$\mathrm{FS}=$ tratamento controle; $F S+A M=$ farelo de soja substituido parcialmente por amiréia; $F S+U R=$ farelo de soja substituido parcialmente por uréia.

${ }_{2}^{2}$ EPM = erro padrão da média. 
Os dados apresentados na Tabela 10 mostram que não foram observadas diferenças $(P>0,05)$ para os teores médios de gordura $(3,98 \%)$, proteina $(3,01 \%)$, lactose $(4,66 \%)$ e sólidos totais $(12,45 \%)$ nos tratamentos estudados neste experimento.

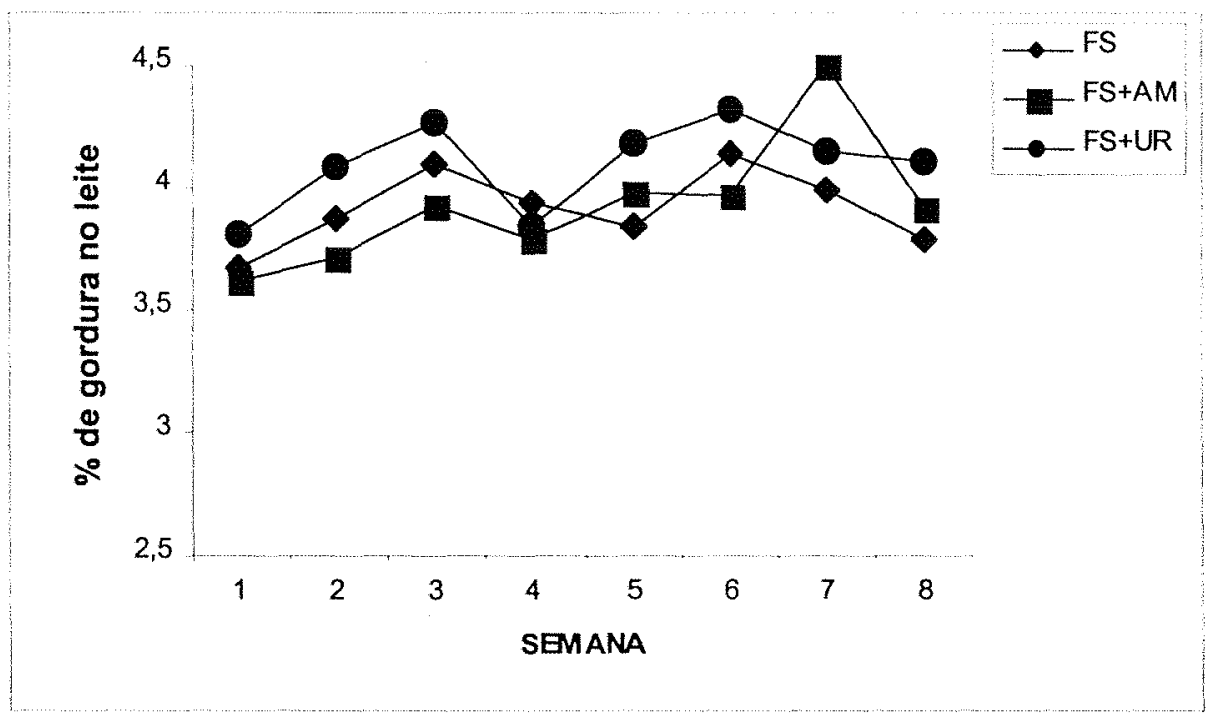

Figura 3 - Teor de gordura do leite durante as oito semanas de experimento.

Neste experimento o teor de gordura não foi afetado pela fonte de $\mathrm{N}$ oferecida às cabras em lactação (Figura 1). A ausência de efeito no teor de gordura mostra que o padrão de fermentação ruminal não foi alterado pela fonte de $N$ utilizada, o uso de dieta total facilita a incorporação de NNP à dieta minimizando efeitos na composição do leite devido a um consumo seletivo (Schingoethe et al., 1993). Semelhante ao ocorrido neste experimento, Fernandez et al. (1997) e Ahmed et al. (2001), ao utilizarem NNP na dieta de cabras leiteiras em lactação, não constaram diferenças no teor de gordura do leite. Do mesmo modo, Santos \& Bose (1985), quando da substituição de 0,4 e 
$0,8 \%$ da MS por uréia. Entretanto, estes mesmos autores, relataram aumento no teor de gordura do leite quando da substituição de farelo de soja e caroço de algodão por $1,2 \%$ de uréia na MS da dieta.

Experimentos com vacas leiteiras demonstraram diminuição do teor de gordura no leite quando da inclusão de uréia (Oliveira et al, 2001; Plumer et al., 1971). Já, Broderick et al. (1993) e Guidi (1999) não demonstraram efeito no teor de gordura pela inclusão de uréia na dieta. Por outro lado, quando da comparação entre farelo de soja, amiréia e uréia, Helmer et al. (1970b), Roman Ponce et al. (1975) e Carmo (2001) relataram maior teor de gordura para o tratamento com uréia, diferentemente deste trabalho, onde não houve diferença para o teor de gordura concordando com os dados obtidos por Jones et al., (1975).

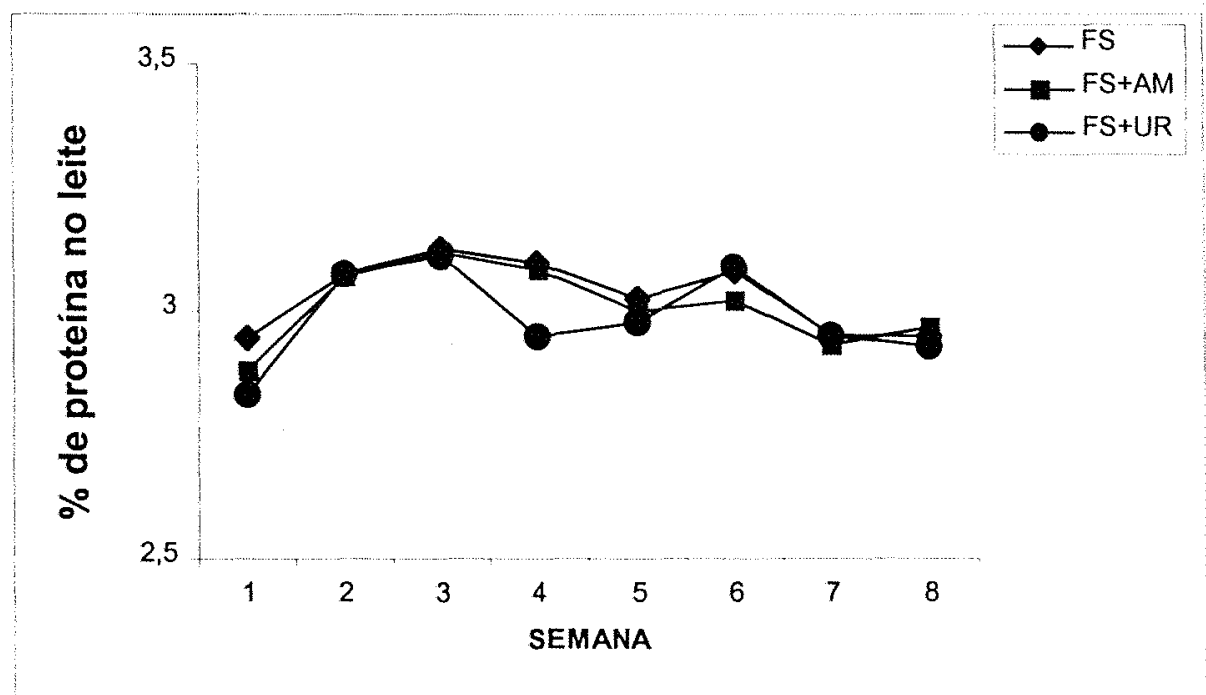

Figura 4 - Teor de proteína do leite durante as oito semanas de experimento. 
O teor de proteina do leite não foi afetado pela fonte de $\mathrm{N}$ utilizada (Tabela 10 e Figura 2), assim como, Roman-Ponce et al. (1975) e Carmo (2001) substituindo parcialmente farelo de soja por uréia ou amiréia em dietas de vacas. Porém, Roman-Ponce et al. (1975) observaram menor produção de proteína devido a menor produção de leite no tratamento com uréia. Já Helmer et al. (1970b), ao comparem amiréia, uréia e farelo de soja, encontraram menor teor de proteína para o tratamento com uréia.

Santos et al. (1998b), em revisão de literatura, relataram que o percentual de proteina do leite de vacas alimentadas com uréia não foi afetado em 17 comparações, aumentou em 5 e foi diminuido em apenas um estudo. $A$ ausência de redução no teor de proteina do leite pode indicar que não houve limitação em proteina metabolizável para o tratamento com uréia (Broderick et al., 1993).

Morand-Fehr et al. (1991) concluiram que a fonte ou a concentração de proteina bruta da dieta, em dietas isoenergéticas e isonitrogenadas, tem efeito limitado em alterar a composição do leite.

\subsection{Concentração plasmática de glicose}

Não foram encontradas diferenças na concentração de glicose plasmática para os três tratamentos (Tabela 11). Em outros experimentos, que avaliaram diferentes fontes e quantidades de $\mathrm{N}$ na dieta para caprinos a concentração plasmática de glicose também não foi afetada pela dieta ( $L u$ et al., 1990; Saluh et al.,1992; Saluh et al., 1993a; Saluh et al., 1993b). 
Tabela 11. Efeito da substituição parcial de farelo de soja por uréia ou amiréia sobre a concentração plasmática de glicose de cabras em lactação.

\begin{tabular}{|c|c|c|c|c|c|}
\hline \multirow[b]{2}{*}{ Glicose (mg/dL) } & \multicolumn{3}{|c|}{ Dietas $^{1}$} & \multirow[b]{2}{*}{$\mathrm{EPM}^{2}$} & \multirow[b]{2}{*}{$P$} \\
\hline & FS & $F S+A M$ & FS+UR & & \\
\hline \multicolumn{6}{|c|}{ Colheita (4 semanas) } \\
\hline $\mathrm{TO} 0^{3}$ & 50,70 & 50,30 & 49,89 & 1,61 & 0,93 \\
\hline T $3^{4}$ & 54,93 & 51,50 & 55,84 & 2,26 & 0,51 \\
\hline \multicolumn{6}{|c|}{ Colheita ( 8 semanas) } \\
\hline TO & 47,58 & 48,90 & 46,40 & 1,55 & 0,61 \\
\hline T 3 & 54,85 & 51,50 & 56,78 & 1,11 & 0,12 \\
\hline
\end{tabular}

Em vacas leiteiras, Broderick et al. (1993) e Imaizumi (2000) não observaram diferença na concentração plasmática de glicose ao utilizarem uréia em dietas para lactação. Carmo (2001) também não observou diferença na concentração plasmática de glicose quando da substituição parcial de farelo de soja por uréia ou amiréia na alimentação de vacas leiteiras em final de lactação.

Segundo o NRC (1989) um excesso de amônia ruminal poderia afetar o metabolismo de glicose. A hiperglicemia geralmente está associada a hiperamonemia, quer seja clínica ou subclínica (Visek, 1984; Fernandez et al., 1990). Neste experimento apesar das concentrações de $N$ uréico plasmático encontradas serem altas (Tabela 12) a concentração de glicose plasmática (Tabela 11) encontra-se dentro do padrão de normalidade descartando assim possibilidade de hiperamonenia subclinica.

Fernandez et al. (1990) demonstraram, em bovinos, que o aumento de glicose relacionado a hiperamonemia é o resultado da reduzida 
secreção pancreática de insulina assim como do desenvolvimento de resistência a insulina pelos tecidos sensiveis a ela. Adicionalmente, em bovinos a produção de glicose hepática foi inibida durante a intoxicação por amônia, logo, a circulação elevada de glicose característica da hiperamonemia é resultante em grande parte ao desenvolvimento de hipoinsulinemia (Fernandez et al.,1988) e ainda a resistência a insulina.

\subsection{Concentração de nitrogênio uréico plasmático (NUP).}

Foi verificada uma menor concentração de $N$ uréico plasmático para o tratamento $F S(P=0,03)$, três horas após a alimentação quando da colheita quatro semanas depois do início de fornecimento das dietas. $\mathrm{Na}$ colheita três horas após a alimentação na oitava semana experimental, houve tendência $(P=0,07)$ a maior concentração de $N$ uréico pelo tratamento $F S+U R$, menor no tratamento $F S$, e intermediária para o tratamento $F S+A M$ a qual foi semelhante a ambos os tratamentos. A concentração semelhante de NUP para os tratamentos $F S+A M$ e $F S+U R$, após quatro semanas, sugere que não existiu diferença na liberação de amônia pelo composto amiréia.

A maior concentração de $\mathrm{N}$ uréico plasmático encontrada nos tratamentos com NNP não está necessariamente associada a alta concentração de $\mathrm{N}$ amoniacal no rúmen, assim como a condição de hiperamonemia. Saluh et al. (1993b), ao trabalharem com teores de proteina na dieta, não demonstraram alteração na concentração de $\mathrm{N}$ amoniacal no rúmen, apesar de terem encontrado aumento do $N$ uréico $(P<0,01)$ associado ao aumento do teor de proteína na dieta. Broderick \& Clayton (1997), após avaliação estatística de parâmetros que influenciam a concentração de uréia no leite e no plasma, concluiram que a associação entre amônia ruminal e NUP é fraca. 
Como já foi relatado por outros autores, em bovinos e caprinos, a concentração de NUP aumentou após a alimentação em ambas as colheitas para todos os tratamentos (Broderick, 1986; Saluh et al., 1992; Saluh et al., 1993b)

Tabela 12. Efeito da substituição parcial de farelo de soja por uréia ou amiréia sobre as concentrações de $\mathrm{N}$ uréico no plasma de cabras em lactação.

\begin{tabular}{|c|c|c|c|c|c|}
\hline \multirow[b]{2}{*}{$\mathrm{NUP}(\mathrm{mg} / \mathrm{dL})$} & \multicolumn{3}{|c|}{ Dietas $^{1}$} & \multirow[b]{2}{*}{$\mathrm{EPM}^{2}$} & \multirow[b]{2}{*}{$P$} \\
\hline & FS & $\mathrm{FS}+\mathrm{AM}$ & $F S+U R$ & & \\
\hline \multicolumn{6}{|c|}{ Colheita (4 semanas) } \\
\hline $\mathrm{TO} 0^{3}$ & 24,90 & 26,97 & 25,48 & 1,30 & 0,47 \\
\hline$T 3^{4}$ & $29,11 \mathrm{Aa}$ & $33,14 \mathrm{Ab}$ & $34,92 \mathrm{Ab}$ & 1,53 & 0,03 \\
\hline \multicolumn{6}{|c|}{ Colheita ( 8 semanas) } \\
\hline TO & 25,35 & 24,75 & 24,42 & 0,92 & 0,74 \\
\hline T 3 & $25,57 \mathrm{~B}$ & $28,17 \mathrm{~B}$ & $30,90 \mathrm{~B}$ & 1,56 & 0,07 \\
\hline \multicolumn{6}{|c|}{$\begin{array}{l}\text { TFS= tratamento controle; } F S+A M=\text { farelo de soja substituido parcialmente por amiréia; } F S+U F \\
\text { soja substituído parcialmente por uréia. } \\
2 \text { EPM = erro padrão da média. } \\
{ }^{3} \text { Tempo } 0 \text { : colheita realizada antes da alimentação. } \\
{ }^{4} \text { Tempo } 3 \text { : colheita realizada três horas após a alimentação. } \\
\text { Letras minúsculas diferentes referem-se a médias que diferem entre si nas linhas, }(P=0,03) \text {. } \\
\text { Letras maiúsculas diferentes referem-se a médias que diferem entre si nas colunas }(P<0,05) \text {. }\end{array}$} \\
\hline
\end{tabular}

Imaizumi (2000), trabalhando com vacas em lactação, não encontrou diferença na concentração de nitrogênio uréico no plasma quando comparou farelo de soja e uréia. Broderick et al. (1993) observaram menor concentração plasmática de $\mathrm{N}$ uréico na dieta quando proteina verdadeira foi fornecida em relação a utilização de uréia como fonte de $\mathrm{N}$.

Owens \& Zinn (1993) sugerem que ao fornecer dieta com uréia ocorre diminuição na taxa de hidrólise no decorrer do tempo. Assim, 
inicialmente quando da alimentação com uréia o consumo de MS e o desempenho diminuem levemente por aproximadamente um mês, retornado a valores normais após este provável período de adaptação. Neste experimento a concentração de NUP mostrou-se alta para ambos os tratamentos com NNP quando da primeira colheita após um mês de experimento, já quando da segunda colheita houve redução na concentração de NUP em relação a primeira para ambos os tratamentos com NNP concordando com os autores acima.

\subsection{Concentração plasmática de ácidos graxos não esterificados (AGNE)}

A concentração plasmática de AGNE não foi afetada pelas dietas experimentais (Tabela 13). Vários experimentos onde diferentes fontes e quantidades de $\mathrm{N}$ foram utilizados na dieta de cabras leiteiras também não evidenciaram alterações na concentração de AGNE (Lu et al., 1990; Saluh et al,1992; Saluh et al, 1993ab). Entretanto, mudanças nas concentrações de AGNE foram demonstradas sobre condições de hiperamonemia induzidas experimentalmente (Fernandez et al., 1990).

Os principais substratos cetogênicos em ruminantes são o butirato absorvido através da mucosa ruminal e os AGNE, assim quando em situações de balanço energético negativo ocorre uma predominância de AGNE (Zammit, 1996). O fato das cabras deste experimento não apresentarem alteração no peso vivo (Tabela 6), ou diferença na concentração de AGNE (Tabela 13) mostra que as dietas experimentais foram capazes de atender as exigências energéticas destes animais. 
Tabela 13. Efeito da substituição parcial de farelo de soja por uréia ou amiréia na concentração de ácidos graxos não esterificados (AGNE) no plasma de cabras em lactação.

\begin{tabular}{|c|c|c|c|c|c|}
\hline \multirow[b]{2}{*}{ AGNE $(\mu \mathrm{mol} / \mathrm{L})$} & \multicolumn{3}{|c|}{ Dietas $^{1}$} & \multirow[b]{2}{*}{$\mathrm{EPM}^{2}$} & \multirow[b]{2}{*}{$P$} \\
\hline & FS & $\mathrm{FS}+\mathrm{AM}$ & $F S+U R$ & & \\
\hline \multicolumn{6}{|c|}{ Colheita (4 semanas) } \\
\hline $\mathrm{TO}^{3}$ & 157,07 & 160,00 & 158,09 & 8,78 & 0,72 \\
\hline $\mathrm{T}^{4}$ & 155,92 & 139,14 & 154,32 & 11,2 & 0,66 \\
\hline \multicolumn{6}{|c|}{ Colheita ( 8 semanas) } \\
\hline TO & 207,90 & 187,14 & 179,38 & 8,48 & 0,23 \\
\hline T 3 & 164,06 & 161,59 & 157,69 & 8,92 & 0,96 \\
\hline
\end{tabular}




\section{CONCLUSÕES}

A utilização de uréia ou amiréia para cabras leiteiras substituindo parcialmente o farelo de soja, em dieta total com silagem de milho (40\%MS) e caroço de algodão $(10 \%)$, pode ser uma alternativa viável para produção de leite. A utilização da amiréia não apresentou vantagem em relação à uréia na dieta utilizada neste experimento. 


\section{REFERÊNCIAS BIBLIOGRÁFICAS}

AGRICULTURAL AND FOOD RESEARCH COUNCIL. The nutrition of goat. Report 10. Nutrition Abstracts and Reviews, v.67, n.11, 1997. 118p.

AHMED, M.M.M., EL HAG, F.M., WAHAB, F.S., SALIH,S.F. Feeding strategies during dry summer for lactating desert goats in a rainfed area under tropical conditions. Small Ruminant Research, v.39, p.161-166, 2001.

ALDERMAN, G. Provisional nutrient standars for goats. London: Agricultural Development and Advisory Service, Agricultural Science Service, 1982. .68p. (Nutrition Chemist's Technical Note).

ASSOCIATION OF OFFICIAL ANALYTICAL CHEMISTS. Official methods of analysis.15.ed. Washington, 1990. 473p.

BAKER, L.D.; FERGUSON, J.D.; CHALUPA,W. Response in urea and true protein of milk to different protein feeding schemes for dairy cows. Journal of Dairy Science, v.78, p.2424-2434, 1995.

BATERMAN, T.G.; MARSHAL, R.T; BELYEA, R.L. KERLEY, M.S.; SPAIN, J.N. Comparision of rumen protected methionine and lysine on blood meal and fish meal as protein supplements for early lactation in Holstein cows. Journal of Dairy Science, v.77, suppl. 1, p.91, 1994.

BENTLEY INSTRUMENTS: Bentley 2000: operator's manual. Chasca, 1995. 77p. 
BLOWEY.R.W. Bovine medicine diseases and husbandry of cattle. Oxford:Blackwell, 1992, p.601-604: Blood Metabolites.

BLOOMFIELD, R.A.; GARNER, G.B.; MUHRER, M.E. Kinetcs of urea metabolism in sheep. Abstr. Journal of Animal Science, v.19, p.1248,1960.

BLOOMFIELD, R.A.; KOMER, R.P.; WILSON, R.P.; MUHRER, M.E. Alkaline buffering capacity of rumen fluid. Journal of Animal Science, v.25, p.1276,1966.

BOIN, C. Uréia para ruminantes, In: SIMPÓSIO SOBRE NUTRIÇÃO DE RUMINANTES, 2, Piracicaba, 1994. Piracicaba: FEALQ, 1994. 198p.

BOYAZOLU, J.; MORAND-FEHR, P. Mediterranean dairy sheep and goat products and their quality: a critical review. Small Ruminant Research, v.40, p.1-11, 2001.

BRODERICK, G. A. Relative value of solvent and expeller soybean meal for lactating dairy cows. Journal of Dairy Science, v.69, p.2958-2968, 1986.

BRODERICK, G.A; A statistical evaluation of animal and nutritional factors influencing concentration of milk urea nitrogen. Journal of Dairy Science, v.80, p.2964-2971, 1997.

BRODERICK, G.A; CRAIG, W.M.; RICKER, D.B. Urea versus true protein as supplement for lactating dairy cows fed grain plus mixtures of alfafa and corn silages. Journal of Dairy Science, v.76, p.2266-2274, 1993.

BRUN-BELLUT, J. Urea recycling in the rumen of dairy goats: effects of physiological stage and composition of intake. Small Ruminant Research, v.23, p.83-90, 1996.

BRUN-BELLUT, J.; ABDULAHAD, N.; VIGNON, B. Effect of fasting and number of daily meals on the variations of uremia and milk urea content in dairy goats. Reproduction Nutritional Development, v.27, p.275-276, 1987. 
BRUN-BELLUT, J.; LINDBERG, J.E.; HADJPANAYIOTOU, M. Protein nutrition and requirements of adult dairy goats, In: MORAND-FEHR, $P$ Goat nutrition: Wageningen: Pudoc: 1991, p. 82-93.

BRUN-BELLUT, J.;LAURENT, F.; VIGNON, B. Urea content in milk and nitrogen utilization in lactating goats. In: INTERNATIONAL SYMPOSIUM PROTEIN METABOLISM AND NUTRITION, Clermont-Ferrand, 1983.Versailles: INRA,1983. p.231

BRYANT, M.P. Symposium on microbial digestion in ruminants: Identification of groups of anaerobic bacteria active in the rumen. Journal of Animal Science, v.22, p.801814, 1963.

BURCHARD,J.F; BLOCK, E. Nutrição do gado leiteiro e composição do leite. In: SIMPÓSIO INTERNACIONAL SOBRE QUALIDADE DO LEITE, Curitiba, 1998. Curitiba: UFPR, 1998. p.87.

CAMPBELL, J.R.; HOWE, W.M.; MARTZ, F.A.; MERILAN,C.P. Effects of frequency of feeding on urea utilization and growth characteristics in dairy heifers. Journal of Dairy Science, v.46, p.131-137, 1963.

CARMO, C.A. Substituição do farelo de soja por uréia ou amiréia em dietas para vacas leiteiras em final de lactação. Piracicaba, 2001.68p. Dissertação (Mestrado) Escola Superior de Agricultura "Luiz de Queiroz", Universidade de São Paulo.

CARVALHO, F.F.R. Efeitos de diferentes niveis de proteina bruta para cabras em lactação e uso de indicadores internos para estimar a digestibilidade dos nutrientes. Viçosa, 1989. 56p. Tese (Mestrado)- Faculdade de Zootecnia, Universidade Federal de Viçosa.

CHALUPA, W. Problems in feedind urea to ruminants. Journal of Animal Science, v.27, p.207-219, 1968. 
CHANEY, A.L.; MARBACH, E.P. Modified reagents for determination of urea and ammonia. Clinical Chemistry, v.8, p.130-132. 1962.

CLARK, J.H.; DAVIS,C.L. Some aspects of feeding high producing dairy cows. Journal of Dairy Science, v.63, p.873-885, 1980.

CLARK, J.H; KLUSMEYER, T.H; CAMERON, M.R. Microbial protein synthesis and flow of nitrogen fractions to the duodenum of dairy cows. Journal of Dairy Science, v.75, p.2304-2323, 1992.

CONRAD, H.R.; HIBBS, J.B. Amounts of urea and efficiency of nitrogen utilization in high producing cows. Journal of Dairy Science, v.61, suppl. 1, abstract.79, 1979

CORDEIRO, P.C.C. Produção de leite de cabra no Brasil. In: REUNIÃO ANUAL DA SOCIEDADE BRASILEIRA DE ZOOTECNIA $38^{\circ}$, Piracicaba, 2001. Anais. Piracicaba: FEALQ, 2001.927p.

DePETERS, E.J.; FERGUSON, J.D. Nonprotein nitrogen and protein distribution in milk of cows. Journal of Dairy Science, v.75, p.3192-3198, 1992.

EASTRIDGE, M.L; ETZKORN, D. The Ohio Dairy Goat Ration Program: version1.0. Ames: The Ohio State University, 1995.

EMERICK, R.J. Nitrate and Urea Toxities. In: $\mathrm{CHURCH,} \mathrm{C.D.} \mathrm{The} \mathrm{ruminant} \mathrm{animal:}$ digestive physiology and nutrition. New Jersey: Waveland Press, , 1993, p.564.

EZEQUIEL, J.M.B.; MATARAZZO, S.V.; SALMAN, A.K.D.; JÚNIOR, A.P.M.; SOARES, W.V.B.; SEIXAS, J.R.C. Digestibilidade aparente da energia e da fibra de dietas para ovinos contendo uréia, amiréia ou farelo de algodão. Revista Brasileira de Zootecnia, v.30, n.1,p.231-235, 2001.

FAO, PRODUCTION YEARBOOOK - 1999, v.56, p.235, 1999. 
FERNANDEZ, J.M.; CROOM Jr., W.J., JOHNSON, A.D.; JAQUETTE, R.D.; EDENS, F.W. Subclinical ammonia toxicity in steers: Effects on blood metabolite and regulatory hormone concentrations. Journal of Animal Science, v.66, p.32593266, 1988.

FERNANDEZ, J.M., CROOM, W.J.Jr., TATE, L.P. Jr., JOHNSON, A.D. Subclinical ammonia toxicity in steers: Effects on hepatic and portal-drained visceral flux of metabolites and regulatory hormones. Journal of Animal Science, v.68, p.17261742, 1990.

FERNANDEZ, J.M., SAHLU, T., LU C. D., IVEY, D., POTCHOIBA M.J. Production and metabolic aspects of nonprotein nitrogen incorporation in lactation rations of dairy goats. Small Ruminant Research, v.26, p. 105-107, 1997.

FUJIHARA, T., TASAKI, I. The effect of abomasal infusion of urea on nitrogen retention in goats. Journal of Agricultural Science. v.85, n.1, p.185-188,1975.

GRAVERT, H.O. Dairy cattle production. Nova York: Elsevier Science, 1987. 234p.

GOERING, H.K; VAN SOEST, P.J. Forage fiber analyses (apparatus, reagents, procedures, and some aplications).. Washington: USDA, ARS, 1970.155p (Agricultural Handbook, 379).

GUIDI, M.T. Efeito de teores e fontes de proteina sobre o desempenho de vacas de leite e digestibilidade dos nutrientes. Piracicaba, 1999. 92p. Dissertação (Mestrado)- Escola Superior de Agricultura "Luiz de Queiroz", Universidade de São Paulo.

GUSTAFSSON, A.H.; PALMQUIST, D.L. Diurnal variation of rumen ammonia, serum urea and milk urea in dairy cows at high and low yields. Journal of Dairy Science, v.76, p.475-479, 1993. 
HADPJIPANAYIOTOU, M. Studies on the response of lactating Damascus goats to dietary protein. Journal of Animal Physiology and Animal nutrition, v.57, p.4152.1986 .

HADPJIPANAYIOTOU, M; MORAND-FEHR, P. Intensive feeding of dairy goats. In: MORAND-FEHR, P. Goat nutrition. Paris: Pudoc Wageningen, 1991. cap.17, p. 197-208.

HAENLEIN, G.F.W. Past, present and future perspectives of small ruminant research. Journal of Dairy Science, v.84, p.2097-2115, 2001.

HELMER, L.G.; BARTLEY, E.E. Progress in utilization of urea as a protein replacer for ruminants: a review. Journal of Animal Science, v.53, n.3, p.331-335, 1971.

HELMER, L.G.; BARTLEY, E.E.; DEYOE, C.W. Feed processing VI- comparision of starea, urea and soybean meal as protein sources for lactating dairy cows. Journal of Animal Science, v.53, n.7, p.883-887, 1970.

HELMER, L.G.; BARTLEY, E.E.; DEYOE, C.W. Feed processing V- Effect of an expansion-processed mixture of grain and urea (starea) on nitrogen utilization in vitro. Journal of Animal Science, v.54, n.1, p.25-51, 1970a.

HERRERA-SALDANA, R.; HUBER, J.T. Influence of varying protein and starch degradabilities on performance of lactating cows. Journal of Dairy Science, v.72, p.1477, 1989.

HOOVER, C.W.; STOKES, S.R. Balancing carbohydrates and proteins for optimum rumen microbial yield. Journal of Dairy Science, v.74, p.3630-3638, 1991.

HOUPT, T.R. Transfer of urea and ammonia to the rumen. In: PHILLIPSON A.T. Physiology of digestion and metabolism in the ruminants. Newclastle: England, 1970. p.119-131. 
HUBER, J.T. Non-protein nitrogen in dairy cattle rations. In: HUBER, J.T.; COOK, R.M. Large dairy herd management. Gainesville: University Press of Florida, 1978. p.293.

HUBER, J.T.; KUNG, Jr., L. Protein and non-protein nitrogen utilization by dairy cattle. Journal of Dairy Science, v.64, p.1176-1182, 1981.

HUNGATE, R.E. The rumen and its microbes. New York: Academic Press, 1966.

IMAIZUMI, $\mathrm{H}$. Avaliação de diferentes fontes e teores de proteína degradável no rúmen sobre o desempenho e parâmetros ruminais e sangüíneos de vacas holandesas em final de lactação. Piracicaba, 2000. 69p. Dissertação (Mestrado) Escola Superior de Agricultura "Luiz de Queiroz", Universidade de São Paulo.

INSTITUT NATIONAL DE LA RECHERCE AGRONOMIQUE. Alimentation des bovins, ovins et caprins. Paris, 1988. 108p.

JENNESS, R. Composition and characteristics of goat's milk. Review. Journal of Dairy Science, v.63, p.1605-1630,1980.

JONES, G.M; STEPHEN, C.; KENSET,B. Utilization of starea, urea or soybean meal in a complete ration for lactating dairy cows. Journal of Dairy Science. v.58,n.5, p.689-695,1975.

LINES, L.W.; WEISS, W.P. Use of nitrogen from ammoniated alfafa hay, urea, soybean meal and animal protein meal by lactating cows. Journal of Dairy Science, $v .79$, p.1992-1999, 1996.

LOOSLI, J.K.; WARNER, R.G. Distillers grains, brewers grains and urea as protein supplements for dairy rations. Journal of Dairy Science, v.41, p.1446-1454, 1958. 
LU, C.D.;POTCHOIBA, M. J.; SAHLU, T.; FERNANDEZ, J.M. Performance of dairy goats fed isonitrogenous diets containing soybean meal or hydrolyzed feather meal during early lactation. Small Ruminant Research, v.3, p. 425-434, 1990.

MAIA, R.L.A; TEIXEIRA, J.C.; PÉREZ, J.R.O. Avaliação da qualidade da amirea (produto extrusão amido-uréia) através do método de estimativa da produção de proteina microbiana "in vitro". In: REUNIÃO ANUAL DA SOCIEDADE BRASILEIRA DE ZOOTECNIA,11., Brasilia, 1985. Anais. Brasilia: Sociedade Brasileira de Zootecnia, 1987. p.95.

MAKKAR, H. P. S.; LADALL, D.; NEGI, S.S. Complexes of urea and formaldehyde as non-protein compounds in ruminant rations. Animal Feed Science and Tecnology, v.20, p.1-12, 1988.

McGREGOR, B.A.; HODGE, R.W. Growth and production of lactating Australian feral does and their Angora cross kids when fed oats with urea or lucerne chaff. Small Ruminant Research, v.1, p.195-201, 1988.

MORAND-FEHR, P; BAS, P.; BLANCHART, G. et al. Influence of feeding on goat milk composition and technological characteristics. In: MORAND-FEHR, P. Goat nutrition. Paris: Pudoc Wageningen, 1991. cap.18, p.209-224.

MORAND-FEHR, P.; BOYAZOGLU, J. Present state and future outlook of the Small Ruminant Sector. Small Ruminant Research, v.34, p.175-188, 1998.

MORAND-FEHR, P. Nutrition and feeding of goats: application to temperate climatic conditions. In: GALL, C. (Ed.). Goat production, London: Academic Press, 1981. p.193-232.

MORAND-FEHR, P.; SAUVANT, D. Alimentation des caprins. In: JARRIGE, R. (Ed.), Alimentation des bovins, ovins et caprins, Paris: Institut Nacional de la Recherche Agronomic, 1988. p.282-304 
MUHRER, M.E.; HARRIS, D.W; BLOOMFIELD. A reacted NPN-carbohydrate complex from urea. Journal of Animal Science, v.27, p.1770, 1968.

NATIONAL RESEARCH COUNCIL. Nutrient requirement of dairy cattle. Washington: National Academy Press, 1989.156p

NATIONAL RESEARCH COUNCIL. Nutrient requirement of goats: angora, dairy, and meat goats in temperate and tropical countries. Washington: National Academy Press, 1981.91p.

NELSON, D.L.; COX, M.M. Lehninger principles of biochemistry.3.ed. New York: Worth, 2000.1152p.

NOCEK, J.E.; RUSSELL, J.B. Protein and energy as an integrated system: Relationship of ruminal protein and carbohydrate avaliability to microbial synthesis and milk production. Journal of Dairy Science, v.71, p.2070, 1988.

ORSKOV, E.R. Protein nutrition in ruminants. San Diego: Academic Press, 1992. $175 p$

OWENS, F.N.; BERGER, W.G. Nitrogen metabolism of ruminant animals: Historical perspective, current understanding, and future implications. Journal of Animal Science, v. 57, p.498, 1983.

OWENS, F. N.; ZINN, R. Protein metabolism of ruminants. In: $\mathrm{CHURCH,} \mathrm{C.D.} \mathrm{The}$ ruminant animal: digestive physiology and nutrition. New Jersey: Waveland Press, 1993. p.564.

OLIVEIRA, A.S.; VALADARES, R.F.D.; VALADARES, S.C. Consumo, digestibilidade aparente, produção e composição do leite em vacas alimentadas com quatro niveis de compostos nitrogenados não protéicos. Revista Brasileira de Zootecnia, v.30, n.4, p.1358-1366, 2001. 
PARKASH, S.; JENESS, R. The composition and characteristics of goat's milk: a review. Journal of Dairy Science, v.30, p.67-87, 1968

PLUMER, J.R.; MILES,J.T.; MONTGOMERY, M.J. Effect of urea in the concentrade mixture on intake and production of cows fed corn silage as the only forage. Journal of Dairy Science, v.54, p.1861-1865, 1971.

RANDY, H.A; SNIFFEN, C.J.; HEINTZ, J.F. Effect of age and stage of lactation on dry matter intake and milk production in Alpine does. Small Ruminant Research, v.1, p.145-149, 1988.

RIBEIRO, S.D.A. Caprinocultura: criação racional de caprinos. São Paulo: Nobel, 1997. 318p.

RINDSIG, R.B. Practical dairy goat feeding. Dairy Goat Journal, v.55, p.12-19, 1977.

ROMAN-PONCE, H; VAN HORN, H.H.; MARSHALL, S.P.; WILCOX, C.J.; RANDELL, P.F. Complete rations for dairy cattle. $V$. Interaction of sugarcane bagasse quantity and form with soybean meal, urea, and starea. Journal of Dairy Science, v.58, n.9, p.1320-1327, 1975.

RUSSEL, J.B. Minimização das perdas de nitrogênio pelos ruminantes. In: SIMPÓSIO INTERNACIONAL EM RUMINANTES, Lavras,1992. Anais. Lavras:UFLA, 1992. p.232-251.

RUSSEL, J.B.; HESPELL, R.B. Microbial rumen fermentation. Journal of Dairy Science, v.64, p.1153-1169, 1981.

RUSSEL, J.B.; OCONNOR, J.D.; FOX, D.G.; VAN SOEST, P.J.; SNIFFEN, C.J. A net carbohydrate and protein system for evaluating cattle diets: I. Ruminal fermentation. Journal of Animal Science, v.70, p.3551-3561, 1992. 
SAHLU, T.; FERNANDEZ, J.M.; JIA, Z.H.; AKINSOYINU, A.O.; HART, S.P. TEH, T.H. Effect of source and amount of protein on milk production in dairy goats. Journal of Dairy Science, v.76, p.2701-2710, 1993a.

SAHLU, T.; HART, S.P; FERNANDEZ, J.M. Nitrogen metabolism and blood metabolites in three goat breeds fed increasing amounts of protein. Small Ruminant Research, v.10, p. 281-292, 1993 b.

SAHLU, T.; FERNANDEZ, J.M.; LU, C.D.; MAINING, R. Dietary protein level and ruminal degradability for mohair production in Angora goats. Journal Animal Science, v.70, p.1526-1533, 1992.

SALMAN A.K.D.; MATARAZZO S.V.; EZEQUIEL J.M.B.; KRONKA S.N.; SEIXAS J.R.C.;SOARES W.V.B.;MARTINS Jr., A. P. Estudo do balanço nitrogenado e da digestibilidade da matéria seca e proteína de rações para ovinos, suplementadas com amiréia, uréia ou farelo de algodão. Revista Brasileira de Zootecnia, v.26, n.1,p.179-185, 1997.

SANTOS, F.A.P.; HUBER, J.T.; THEURER, C.B.; SWINGLE, R.S.; SIMAS, J.M.; CHEN, K.H.; YU,P. Milk yield and composition of lactating cows fed steam-flaked sorgum and graded concentrations of ruminally degradable protein. Journal of Dairy Science, v.81, p.215-220, 1998a.

SANTOS, F.A.P.; SANTOS,J.E.P.; THEURER, C.B.; HUBER, J.T. Effects of rumenundegradable protein on dairy cow performance: a 12-year literature review. Journal of Dairy Science, v.81, p.3182, 1998b.

SANTOS, L.E.; BOSE, M.IV. Produção de leite em caprinos alimentados com niveis crescentes de uréia. Boletim da Indústria Animal, v.42, p.11-30, 1985. 
SANTOS, F.A.P; JUCHEM, S.O; IMAIZUMI, H. et el. Suplementação de fontes de proteína e de amido com diferentes degradabilidades ruminais para vacas em lactação. In: REUNIÃO ANUAL DA SOCIEDADE BRASILEIRA DE ZOOTECNIA, 37; Piracicaba, 2001. Anais. Piracicaba: FEALQ, 2001. p. 1544.

SAS INSTITUTE. SAS/STAT user's guide. 7.ed. Cary, 1999. 210p.

SATTER, L.D.; ROFFLER, R.E. Nitrogen requirements and utilization in dairy cattle. Journal of Dairy Science, v.58, p.1219-1237, 1975.

SCHINGOETHE.D.J; BYERS, F.M.; SCHELLING, G.T. Nutrients needs during critical periods of the life cycle. In: $\mathrm{CHURCH}$, C.D. The ruminant animal: digestive physiology and nutrition. New Jersey: Waveland Press, 1993. p.564.

SCHMIDT-NIELSEN, K. Fisiologia animal: adaptação e meio ambiente. 5.ed. Trad. de T.Oppino e C. Finger. São Paulo: Livraria Santos, 1996.600p.

SEIXAS, J.R.C.; EZEQUIEL, J.M.B.; ARAUJO, W.A. ET AL. Desempenho de bovinos confinados alimentados com dietas à base de farelo de algodão, uréia ou amiréia. Revista Brasileira de Zootecnia, v.28, n.2, p.432-438, 1999.

SINGHAL, K.K.; MUDGAL, V.D. Effect of urea and biuret feeding on water metabolism in growing and lactating goats. Indian Journal of Animal Science, v.50, p.161$164,1980$.

SINGHAL, K.K.; MUDGAL, V.D. Urea and biuret as a protein supplement for goats fed with straw. Indian Journal of Animal Science, v.52, p.80-85, 1982.

SINGHAL, K.K.; MUDGAL, V.D. Biuret and urea in the ration of milk goats: full lactation study. Indian Journal of Animal Science, v.54, p.180-189, 1984. 
STILES, D.A.; BARTLEY, F.E.; MEYER, R.M. Feed Processing. VII Effect of na expansion- processed mixture of grain and urea (starea) on nitrogen utilization in cattle and on urea toxicity. Journal of Dairy Science, v.53, p.1436,1970.

SUTTON, J.D.; ALDERMAN, G. The energy and protein requirements of pregnant and lacting dairy goats: The Agriculture and Food Reserch Council report. Livestock Production Science, v.64, p. 3-8, 2000.

TEIXEIRA, J.C.; EVANGELISTA, A.R.; ALQUERES, M.M. et al. Utilização da amiréia150s como suplemento nitrogenado para bovinos em sistema de pastejo. In: REUNIÃO DA SOCIEDADE BRASILEIRA DE ZOOTECNIA, 35. Botucatu, 1998. Anais. Botucatu: SBZ, 1998. p.482-484.

TYRELL, H.F; REID, J.T. Prediction of the energy value of cow's milk. Journal of Dairy Science, v.48, p.1215-1223, 1965.

VISEK, W.J. Ammonia: It's effects on biological systems, metabolic hormones, and reproduction. Journal of Dairy Science, v.67, p.481-498, 1984.

WILSON, G.; MARTZ,F.A.;CAMPBELL,J.R.; BECHER,B.A. Evaluation of factors responsible for reduced voluntary intake of urea diets for ruminants. Journal of Animal Science, v.41, p.1431-1437, 1975.

ZAMMIT, V.A. Role of insulin in hepatic fatty acid partitioning: emerging concepts. Biochemical Journal, v.314, p.1-14, 1996. 